

Digitized by the Internet Archive in 2011 with funding from University of Toronto 




\section{CONTRIBUTIONS OF THE} ROYAL ONTARIO MUSEUM OF ZOOLOGY

No. 15. THE FISHES OF THE OTTAWA REGION.

By J. R. DyMond

Published under

THE REUBEN WELLS LEONARD BEQUEST 



\section{THE FISHES OF THE OTTAWA REGION}

\section{By J. R. Dymond}

The Ottawa region has an unusually interesting fish fauna. This is due to the wide variety of ecological conditions and to the geological history of the area. Included in the region are waters of all sizes from the Ottawa river with its great lake-like expansion known as lake Deschenes, to tiny ponds and brooks. To the north is the rocky Laurentian highland containing numerous lakes and streams; the lakes are often rock-bound and the streams rapid. To the south is a comparatively level, low-lying plain formed of alluvial deposits. The latter region contains few lakes and its streams for the most part are slow-flowing.

The upper Ottawa was once connected with lake Nipissing which at that time was a bay of glacial lake Algonquin, the precursor of lakes Huron and Superior (Coleman 1922). The fish of these upper Great Lakes therefore had access to the Ottawa and many of its tributary waters. Similarly a connection with the St. Lawrence and lake Ontario was afforded by the Rideau, while the Ottawa itself has provided an avenue for the arrival of species of still more eastern origin.

A feature of its geological history responsible for the presence of the smelt (Osmerus mordax); the shad (Alosa sapidissima) and probably the two-spined stickleback (Gasterosteus aculeatus) in the Ottawa region is the incursion of the sea which followed the withdrawal of the ice sheet of the last glacial epoch. These are marine species of the Atlantic seaboard; their presence in the Ottawa area are undoubtedly as relics of the time when the Ottawa valley was an arm of the sea. Marston's trout (Salvelinus marstoni) probably owes its origin to the same circumstance.

The fall fish (Leucosomus corporalis) is a species of the Atlantic seaboard which in the Ottawa valley has penetrated farther to the westward than it has done to the south. To the former intimate connection with the Great Lakes is undoubtedly due the presence of such species as the garpike (Lepisosteus osseus), bowfin (Amia calva), sheepshead (Aplodinotus grunniens), and channel catfish (Ictalurus punctatus).

The variety of game and commercial fish of the Ottawa region is an indication of the wide range of conditions found in this area. Most of the game fishes of eastern North America are to be had within a short distance of Ottawa. These include speckled trout, lake trout, Marston's trout, small- and large-mouth black bass, maskinonge, yellow pickerel and pike. The commercial species include sturgeon, mooneye, shad, whitefish, lake herring, sucker, channel catfish, bullhead, eel, perch and sunfish. 


\section{History of the Fisheries of the Ottawa Region.}

The distinction between game and commercial species is of comparatively recent origin. For many years after the fisheries of the Ottawa region began to be exploited all kinds were caught and sold commercially. In this way considerable quantities of fish were taken by commercial fishermen from the Ottawa river and the lakes and streams of the Gatineau area. Among the fishery overseers' and guardians' reports for the province of Quebec for the year 1870, contained in the Third Annual report of the Department of Marine and Fisheries, there is the following report of W. L. Holland, overseer for the Ottawa division.

"Owing to the increasing importance of the fisheries in this division, it was found necessary to appoint a special guardian. The lakes in the counties of Ottawa and Pontiac are teeming with speckled and grey trout, bass, whitefish, etc. To the new settler as well as to the sportsman, these waters afford ample means of subsistence and pleasure. The want of a proper guardian, and the belief under which parties were that the fish belonged to them, induced them to destroy them at all times, in season and out of season, with nets and spears. It was found highly necessary to put a stop to these lawless practices. Quite a number of nets have been seized, and the law being now better known will be better observed.... Hitherto these inland waters have been most wastefully and persistently fished, in the interests of American dealers, who contract for the fish, to be delivered to them for sale in the United States markets, where they command high prices and are in great demand."

This report contains no record of commercial fishing in this area in Ontario.

That the creation of conditions detrimental to fish life soon manifested itself is shown by the report of the same officer. In 1873 he reported for the Ottawa division (Quebec) :

"I find an increase of fish in all parts of Ottawa County, and the people inform me that it is the result of the protection which has been exercised by the Department over the lakes of this district. They complain, however, that the lumbermen injure the fisheries by erecting dams at the outlets of lakes, thus preventing the fish from reaching their spawning beds. In places where these dams have been constructed, the yield of fish has decreased and the residents of such localities complain of the fact. The system of protection to the fisheries has proved so advantageous to the fishermen that many of them who formerly fished all through the close season, and only complied with the provisions of the law through compulsion, now recognize the wisdom of the Department in this matter, and aid the overseer in protecting the fish.

"I would recommend that the close season for speckled trout on lakes, commence on the first of October and continue until the first of May, in each year, and that this order be enforced on all lakes within a distance of thirty miles from the Ottawa River; that dams erected by lumbermen at the outlets of lakes be so constructed that the fish may have access to the upper waters, and when erected that they do not raise the water to more than the usual high spring level. This practice of the lumbermen, I find, is very injurious to the fisheries of this County."

The report for 1875 contained in Supplement No. 4 to Eighth Annual 
Report of the Minister of Marine and Fisheries contains the following statement of the overseer for the Madawaska river and Lake des Chats division, Ontario, "Fish were not so numerous this season as on previous years owing principally to sawdust and mill rubbish, which has accumulated at the mouth of the Madawaska river and Lake des Chats." The yield of fish for this division is given in barrels as follows: whitefish 15, maskinonge 10 , bass 25 , pike 15 , pickerel 20 , coarse fish 80 .

The same report contains the following statement with reference to the Ottawa division, in the province of Quebec.

"This division was guarded during the present season by special constables detached from the Dominion Police Force and local Fishery guardians located at the most central places.... Parties fishing with nets for purposes of trade and commerce either in the Ottawa River or in the lakes are compelled to provide themselves with licenses to do so. These are issued to them free of charge-most of the parties being poor people whom the hard times and decline in the lumbering operation had thrown out of employment-No less than 160 licenses were thus issued during the present season-seventy-eight licenses were granted to residents for the privilege of fishing in lakes of this division and eighty-two licenses were also granted for spring and summer fishing in the Ottawa River."

The report contains no record of the catch.

Some idea of the extent of the fishery at this time is afforded by the estimates of the yield for 1881 in the upper Ottawa and Gatineau lakes division of the province of Quebec given in supplement. No. 2 to the Fourteenth Annual Report of the Department of Marine and Fisheries as follows, in pounds : trout 154,000 , whitefish 23,700 , bass 12,950 , pike 51,400 , pickerel 8,800, maskinonge 1,800, sturgeon 5,000, mixed fish 25,000; and eels to the number of four thousand. The catch in Carlton and Russell counties for the same year is given as 100 barrels of coarse fish.

According to the report of the Fisheries Branch, Department of Marine and Fisheries for 1899, the yield of fisheries on the Quebec side of the Ottawa river from Carillon to Pontiac for the year 1898 was as follows, in pounds: trout 650 , bass 46,250 , pickerel 54,750 , pike 58,250 , maskinonge 26,650 , sturgeon 63,450 , eels 18,000 , perch 42,000 , catfish 55,850 , mixed and coarse fish 82,850. The same report gives the returns for the Gatineau Lakes as: whitefish 9,200 , trout 95,300 , bass 14,100 , pickerel 12,750 , mixed and coarse fish 8,000. On the Ontario side (Prescott and Carleton counties) the catch was whitefish 600 , bass 9,950 , pickerel 7,270 , pike 9,500 , maskinonge 11,100 , sturgeon 1,250 , eels 8,800 , perch 9,000 , catfish 41,100 , mixed and coarse fish 57,900 .

This is a total of over seven hundred thousand pounds of fish taken from the waters of the Ottawa region in one year. Of this, 70,300 pounds was bass and 37,750 pounds, maskinonge. 
Overseer Joseph Marion in reporting on the fisheries of the upper Ottawa and Ciatineau lakes division for the year 1891 said, "There were fifty-one men fishing this season for local markets and their catch consisted chiefly of maskinonge, pickerel, pike, sturgeon, carp, suckers, catfish, etc. These fish are disposerl of on the Ottawa markets at ten cents per string of fish averaging two pounds each."

There is little doubt that such catches are in excess of the annual productivity of the waters and that therefore the stock of fish was steadily depleted by such exploitation. For instance, the statistics quoted below in discussing the maskinonge indicate that at least 300,000 pounds of this species were removed from the waters of the Ottawa region between 1881 and 1907. For a period centring on 1898 the annual catch was in the neighbourhood of 35,000 pounds. In the case of bass the corresponding figures were 600,000 pounds total catch and 70,000 pounds annual catch in 1898.

When one remembers that, at the time the fisheries were being subjected to this drain, the waters were also being heavily polluted, one is inclined to marvel, not that fish are now so scarce, but rather that there are any fish at all left.

An indication of the extent of pollution is given in the report of the Department of Marine and Fisheries for 1897 where it is reported that on the Quebec side of the Ottawa river sawdust and rubbish were allowed to pollute the river to such an extent that when it was windy the fishermen's nets became full of debris and were thereby injured, if not ruined. The waters of Campbell's Bay became so polluted that cattle refused to drink it, and if holes were made through the ice an obnoxious odour emanated from them.

Until 1899 the fisheries were administered by the federal government but in that year, as a result of a decision of the Privy Council, the provinces of Ontario and Quebec took over supervision of their inland fisheries.

Some indication of the condition of the fisheries at that time is given in the first annual Report of the Ontario Fisheries Branch for the year 1899 in which it is recorded that in the Ottawa river below the Chaudiere falls fishing had not been so good as it had been a few years earlier: this was attributed to the constant increase of sawdust and mill refuse thrown into the river; on the Rideau fishing had been very fair but nothing like it was a few years earlier: a recommendation is made that the Quebec Government be requested to do away with the granting of licenses for net fishing in lake Deschenes and all the river between Ottawa and lake Deschenes.

In the same report it was recommended that the sale and export of all game fish,--speckled trout, small and large-mouth bass and maskinonge 
- be prohibited for a period of not less than three years. This regulation was put into force in 1900, when the sale or export of speckled trout, large and small-mouth black bass and maskinonge was prohibited for a period of three years, or until July 1, 1903, except for the usual provision for the export of fish caught by tourists. At the same time, the minimum size of the various species which might be retained was fixed at ten inches for bass, six inches for speckled trout and eighteen inches for maskinonge. In 1903, the sale of speckled trout, bass and maskinonge was prohibited for a further period of three years. The regulation prohibiting the sale of game fish, although passed in 1900, did not become effective, at least for bass and maskinonge, until 1901.

Under an arrangement between the provinces of Ontario and Quebec, no fishing by nets is now permitted in the Ottawa river. There are, however, a few commercial hook licenses issued by the two provinces.

Agitation against the sale of game fish had been carried on for some years previous to 1900. The "Empire" of Toronto on November 19, 1894, published the report of a committee appointed by the International Anglers Convention to draw up recommendations for the conservation of black bass. Among the measures recommended by this committee was the following, "Your committee would further recommend that the sale of bass (both species) be prohibited from the 1st day of December to the 15 th day of June each year as this would remove the principal inducement that now exists for the reckless destruction of this valuable fish."

\section{InADEQUACY OF EARLy Fisheries Statistics.}

It is impossible to get any clear idea of the trend of the early fisheries because of the unsatisfactory way in which the statistics are presented. For scarcely two years in succession were catches given for the same region. For instance, for 1896 statistics are given separately for "Ottawa river fronting on counties Ottawa and Pontiac" and "Gatineau lakes". For 1898 the catches given are for "Ottawa river, Carillon to Pontiac" and "Gatineau lakes and vicinity" and for 1900 for "Ottawa river and tributaries". In Ontario there are catch statistics for 1898 for Prescott and Carleton, for 1899 for Frontenac, Leeds, Carleton, Prescott and Russell and for 1900 for Prescott, Russell, and Carleton. If it had been the object of the statistician to make it impossible to trace the trend of the fishery from year to year he could hardly have been more successful than he has been. Proper statistics are a fundamental need of the fishery biologist, and it is to be regretted that so many of our records are so difficult to use. 


\section{EARLy Introductions.}

Although bass, maskinonge and yellow pickerel are all native to the ()ttawa region, introductions of these species from other areas were carly mate according to Small (1883) who says, "I am informed that many of the bass now in that bay (Camplell's) were brought from the Bay of (Uunté, or from the ()ttawa lakes; maskinonge from Rice lake and doré from the Detroit river and from lake Huron."

\section{Published Accounts of Ottawa Fishes.}

Apart from Small's (1883) account of the fishes of the Ottawa district, comparatively little has been published on the fish life of this area. Earlier accounts of the fish of the region are mentioned by Small in the following words, "I am indebted to the President of this Club, (Ottawa FieldNaturalists' Club) Mr. (James) Fletcher, for reference to lists published by the Ottawa Natural History Society of 1859-1863, which are in his possession, and in which certain fishes are mentioned as belonging to the Ottawa district, but presumably that meant the Ottawa river generally. They do not comprise all the fish I now mention, and they allude to three of which I an very dubious, viz., the ribbon fish, the splendid pike and the red-bellied minnow, enumerating each of these as a different species. They also mention the shad, to which, however, I shall allude in its proper place."

Mr. Aurèle LaRocque has kindly supplied me with photostat copies of a number of articles from the Ottawa Citizen which undoubtedly include two of those referred to by Small. The first of these is entitled "No. 1Minnow Lake, Notes on the Lakes and Lake Fishes in the Vicinity of Ottawa, C. W. (Canada West) by a member of the Isaac Walton Club." Small believed the writer of this was Dr. Van Cortlandt. This was published in the Citizen on June 21, 1865. The second article is entitled "Fishes of the Ottawa. A Digest of an Essay on the Fishes of the Ottawa River, with its tributaries and some of the Contiguous Lakes-Read before the Natural History Society on Friday, 24th Nov., 1865, by Edward Van Cortlandt, M.D., Curator of the Society." This appeared in the Citizen on November 29, 1865.

Although Reports of the Zoological Branch of the Ottawa FieldNaturalists' Club were published in the Naturalist for a number of years, they contain comparatively few records of fish from the Ottawa area. Mention is made of specimens taken in other parts of Ontario, at our Atlantic and Pacific coasts and even Africa. It seems to be a common human failing to regard that which is distant as more interesting than that which is at hand.

In the report for 1902 Macoun et al. (1903) remark, "One member 
of the Club, Mr. Andrew Halkett, is able to record the examination of a great variety of Teleostean fishes from various localities in Ontario and Quebec. These are being preserved to form the nucleus of a new collection of fishes in connection with the Marine and Fisheries Department." The report for 1906 contains a list, prepared by Mr. Halkett of the fishes of the Ottawa district preserved in the Fisheries Museum with the localities where they were taken. Mr. Halkett's "Check List of the Fishes of the Dominion of Canada and Newfoundland" published in 1914 grew out of his work with the Canadian Fisheries Museum.

Of the species included in the present account, Small (1883) discusses about forty. The exact number cannot be determined since the identity of a few is uncertain. However, Small's account is, on the whole, excellent, his omissions being chiefly minnows and other small forms.

\section{Source of Information and Acknowledgments.}

The basis of the following list is a collection made in numerous lakes and streams in the Ottawa district in August 1937. In this field study I had the assistance of Mr. and Mrs. G. C. Toner, Miss Isobel Limbert and Mr. Aurèle La Rocque. My thanks are due them for their generous and effective assistance. To Mr. La Rocque I am further indebted for much other assistance including the searching of the files of old Ottawa newspapers and abstracting articles and notes on fishes.

Mr. J. C. McCuaig, Secretary-treasurer of the Fish and Game Protective Association for the counties of Gatineau, Hull, Papineau and Pontiac, also gave invaluable assistance. Mr. McCuaig's long acquaintance with the region and his active interest in its fish life has given him an extensive knowledge of the distribution and history of fish life in this area. His fund of information has been freely at my disposal. For his generous co-operation I am deeply indebted.

Special thanks are also due Mr. J. A. Rodd, Superintendent of Fish Culture of the Fisheries Department for generous assistance in securing specimens and supplying information.

It is impossible to mention all who have aided in the accumulation of the information contained in this report. To all the following I am especially grateful for specimens or information: Messrs. G. J. Doane, Geo. Lamb, Clyde Johnson, Emile Latremouille, L. H. Newman, Max J. Runge and J. P. Turner of Ottawa, Rev. Ewen J. Macdonald of Alexandria, Rev. Philip Caiger-Watson of Galetta, J. O. Clark of Smith's Falls and D. P. Jarrett of Chaffey's Locks.

Published information used has been acknowledged in the list of literature at the end of the account. 
Northern Lamprey. Ichthyomyinon unicuspis Hubbs and Trautman.

According to Hublos and Trautman (1937), this is the lamprey designated as Ichthyomy'non concolor by Jordan and Evermann (1896) and most subsecpuent authors. Its distribution includes "the Saint Lawrence river from the vicinity of (Duebee to the outlet end of lake Ontario, including lake Champlain and other tributary waters at relatively low elevations."

Hubbs and Trautman regard the following records from the Ottawa locality as referring to this species: Ricleau, Gatineau and Lièvre rivers and tributaries as I. argenteus, Small 1883: Brigham's Creek, Hull, P.Q., "north river Ottawa" as I. bdellium Huntsman 1917, and Ottawa river, Halkett (1906B).

An ammocoete from the Ottawa river, south side of Kettle island, near Ottawa, Oct. 8, 1936, is regarded by Dr. Hubbs as probably belonging to Ichthyomy ron unicuspis. Another ammocoete taken in a creek tributary to the Ottawa at Montebello, Sept. 12, 1928, was identified by Dr. Hubbs as Entosphenus lamottenii or Petromyzon marinus. The ammocoete distinctions between these species are unknown. Lampreys of undetermined species are reported from Deschenes rapids and the mouth of Lièvre river.

Lake Sturgeon. Acipenser fulvescens Rafinesque.

Sturgeon were formerly found in some numbers in the lake-like expansions of the Ottawa river. Halkett (1912) recorded a specimen five feet six inches long from Lake Deschenes. The species is also said to occur in Calabogie lake on the Madawaska and Big Gull lake on the Mississippi.

The catch on the Quebec side has always been greater than that in Ontario. On the latter side, the catch has rarely been as large as five thousand pounds a year; usually it was less than two thousand pounds in Prescott, Russell, Carleton and Renfrew counties combined. The following records, selected from the statistics of the commercial catch on the Quebec side of the river, will indicate something of their abundance. The areas to which the records refer vary from one period to another in the reports of the Department of Marine and Fisheries as shown.

Commercial Catch of Sturgeon in Pounds.

1881

1896

1898

1901

1902

1903

1904

1906

1907
Upper Ottawa and Gatineau lakes division

Ottawa river fronting on counties Ottawa and Pontiac

Ottawa river, Carillon to Pontiac

Ottawa river and tributaries

" " " "

"6 " " 6

" " " " "

" 6 "

6 " 64 (including Gatineau district)

(Pontiac and Ottawa counties

$\begin{array}{llll}\text { " } & \text { " } & \text { " } & \text { " } \\ \text { " } & \text { " } & \text { " }\end{array}$

" $"$ "
35,300

39,100

18,500

14,300 
For the years 1908 to 1916 inclusive, the catch for the Ottawa district is not given separately from other inland areas. Since that time, the catch has fluctuated rather widely from 200 pounds in 1922 to 16,800 pounds in 1931. The usual catch has been about 4,000 pounds a year, but for the years 1929, 1930, 1931 and 1932, it was $11,200,12,100,16,800$ and 2,200 pounds respectively.

Long-nosed Gar Pike. Lepisosteus osseus (Linnaeus).

Gar pike are occasionally taken in the Ottawa and Rideau.

Small (1883) reported them as, "found in the Ottawa River and its tributaries, although far more abundantly in the former than in the latter". "One . . caught in a scoop net at the foot of the locks here in Ottawa," Small (1893). Halkett (1907) had "specimens from Ottawa river, Lake Deschenes and Gatineau river, P.Q."

Bowfin: Dogfish. Amia calva Linnaeus.

The only record I have of this species is that of Halkett (1906B) who says, "The two specimens of dog-fish (Amia calva) have been long in the Museum and are labelled Ottawa River. Possibly they may have been found beyond the limits of the district, but are included in the list as showing that that species exists in the Ottawa."

Moon-eye. Hiodon tergisus Le Sueur.

Specimens of moon-eye said to have been taken on the Quebec side of the Ottawa river between Hull and Buckingham were purchased on the Ottawa market on September 1, 1937.

Small (1883) says the species was "Caught abundantly in the Ottawa in summer . . a affords excellent sport in July and August taking a grasshopper and worm eagerly." Halkett (1914A\&B), also records it from the Ottawa. Mr. McCuaig says these fish are often called "River whitefish" and that they occur in abundance in the Ottawa as far as Lake Timiskaming.

Shad. Alosa sapidissima (Wilson).

Shad are still found in the Ottawa in spring. They appear each year at the end of May or beginning of June at Point Fortune, where their upstream migration is stopped by a dam. It is believed that some occasionally are able to ascend the Ottawa above Point Fortune. John Pilon, a commercial fisherman at L'Original, lists "Alose" as occurring in the Ottawa at that point. There is reason to believe that some at least of the shad were able to surmount the Carillon rapids at Point Fortune before the construction of the dam. Rev. Ewen Macdonald of Alexandria states (1938), 
"We are sure that the shad were taken aplenty at Chute-au-Blondeau (four miles above Point Fortune). There was there a very convenient rock ledge. It is now covered hy the waters, backed up by the dam. It seems that the rough waters of the narrows drove the shad near this ledge. It was the fishing hole 'par excellence'.... One old gentleman told me he knows that a certain farm near Chute-au-Blondeau was fertilized by cart loads of shad which could not be sold. . . Mr. Kirby is the name of the present owner of the farm where the famous rock ledge is. . . His father was the wholesale shad fisherman of the days before the construction" (of the dam).

The late Chief Justice I atchford in a letter dated February 11, 1937, said, "I am told that one Kirby brought an action to have the dam at Carillon so changed that the shad could get up the Rapids."

Small (1883) says, "The shad (Alosa sapidissima) is another fish which is of doubtful question as coming up the Ottawa above Grenville. They are well known as frequenting the Ottawa up to Carillon, but above that only a stray fish once in a way probably ascends and the beds of sawdust which extend everywhere above Carillon would hardly invite these delicate fish to pursue their wanderings any farther. I find the shad recorded in lists of 1860 , but then there was no limit assigned to these lists, simply 'fishes of the Ottawa'."

Wright (1892), Nash (1908) and Halkett (1914A) all state that although it was formerly abundant in the lower Ottawa, the shad had abandoned its former spawning grounds in that area due to the pollution of the river by sawdust. On the contrary Mr. Macdonald states that shad have been coming up to Point Fortune in spring "about the time of the cherry blossoms for over one hundred years."

The occurrence of shad in this area is believed to be a survival of the time, following the retreat of the last glacier, when an arm of the sea extended up the Ottawa valley to the head of lake Timiskaming (Coleman 1922). The shad normally spends the greater part of its life in salt water, resorting to fresh water only at spawning time. Whether the shad which visit the Ottawa spend their whole lives in fresh water or come from the Gulf of St. Lawrence or still farther away is not known. There was formerly a considerable fishery for shad in the St. Lawrence and L. Tremblay of the St. Lawrence Biological Station informs me that shad are still taken at the end of May and beginning of June at L'Ile Verte.

\section{Whitefish. Coregonus clupeaformis (Mitchill).}

The whitefish is found in the Ottawa river especially in such lake-like expansions as lake Deschenes and in the larger, deeper lakes of the Gatineau, Lièvre and Blanche watersheds. Small (1883) said it was "found in many of the lakes of the Gatineau and Lièvre district where it is both netted and speared." 
Commercial fishing for whitefish dates back at least to 1875 for which year the reports of the Department of Marine and Fisheries give 15 barrels as the catch for the Madawaska river and Lake des Chats division of Ontario. The areas for which the catch is given vary from period to period in these reports, but the following records selected from the statistics of the commercial catch will give some indication of the abundance of whitefish in previous years.

Commercial Catch of Whitefish in Pounds

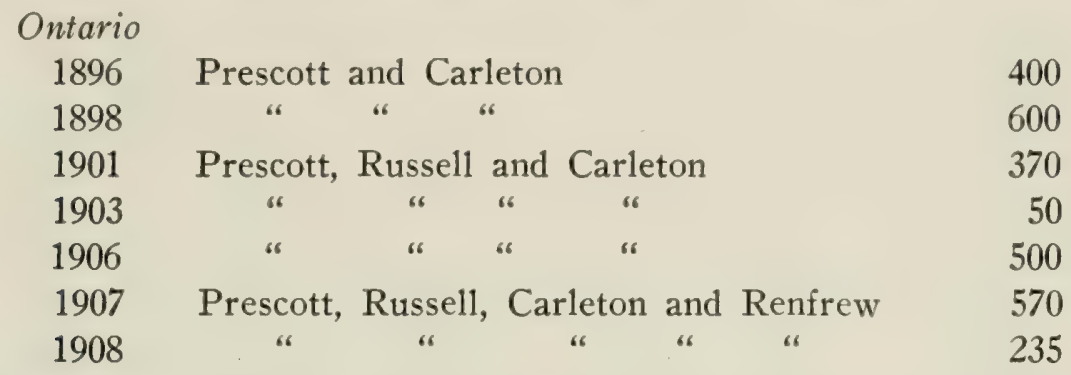

(Not given separately from other inland waters in subsequent reports, except for 1920, 1921 and 1922 in which no whitefish taken.)

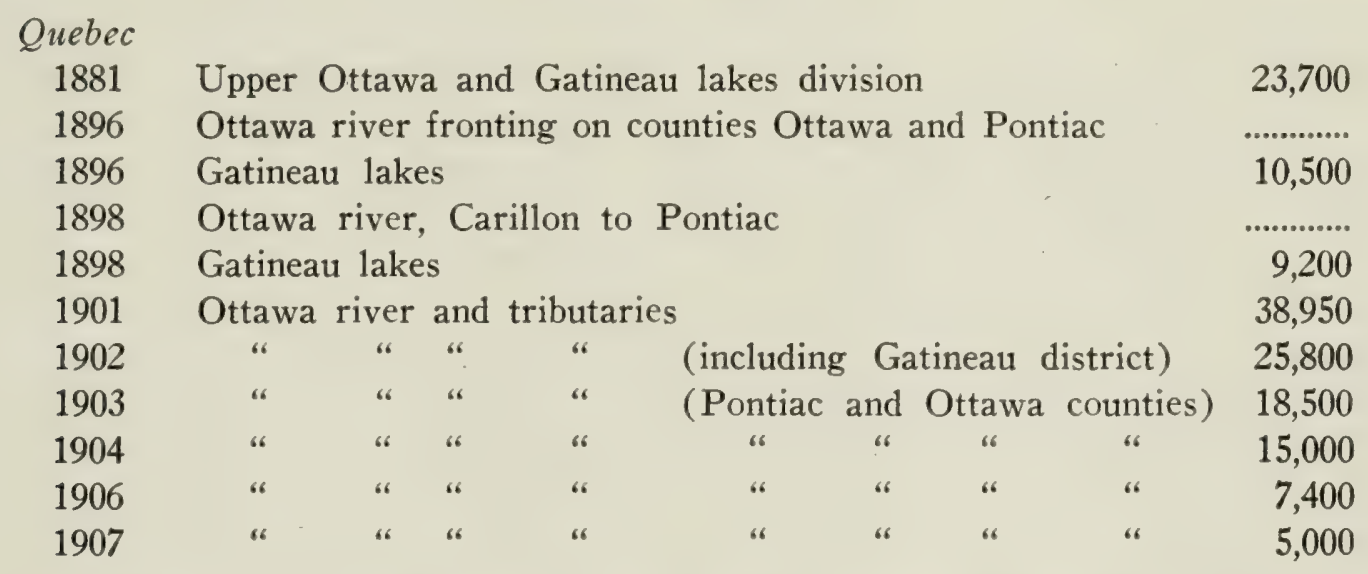

These figures indicate that the Gatineau lakes were probably the mainstay of the commercial fisheries for whitefish. Mr. McCuaig states that for years, and to some extent still, whitefish provided winter food for many people in the lake area to the north of Ottawa. They were taken during the spawning run in November. During the summer, they were taken in Baskatong and Grand Lac Poisson by commercial fishermen.

For the years 1908 to 1916 inclusive, the catch for the Ottawa district is not given separately from other inland areas in the fisheries statistics.

Since 1917, the catch, chiefly taken in Pontiac county, has varied widely from year to year, as indicated by the following returns for the most recent years.

$\begin{array}{cccc}1933 & 0 & 1935 & 6,000 \text { lbs. } \\ 1934 & 6,000 \text { lbs. } & 1936 & 0 \\ & & 1937 & 6,000\end{array}$




\section{Lake Herring. Leucichthys artedi (Le Sueur).}

The lake herring is found in many of the lakes which contain lake trout. Like the trout, it will survive only in lakes having a sufficient body of deep, cold water in which to live during the summer. The lake herring is an important foorl of the lake trout and since a large part of its food consists of almost microscopic crustaccan organisms it serves as a link between these tiny animals and the trout. In lakes lacking some such fish as lake herring, where trout must live on very small creatures they never reach a large size. In a few lakes the place of lake herrings as intermediates in the food chain is taken by whitefish, smelts and occasionally minnows, but lake herrings are the ideal trout food because of their habit of resorting to the trout's deep water habitat in summer.

Mr. McCuaig has supplied me with the following list of lakes in which lake herring occur: McGregor, Grand, McArthur (Dowler), Wakefield, McMullen, McFee, Dam, Marble, Meach, Harrington (Mousseau), Philippe, Lapêche (Wilson's), Donaldson, Battle, Rhéaume, Sucker (Carrol), Terror. Evermann and Goldsborough (1907) record this species from "Thirty-one Mile lake, sixty miles north of Ottawa", the authority being a letter dated May 11, 1897, describing a fish 14.5 inches long caught by Gen. D. D. Wylie in Thirty-one Mile lake and sent to U.S. Fish Commission for identification by a Mr. Shields. This record is repeated by Halkett (1914A).

In our experience, a size of $14 \mathrm{I} / 2$ inches is unusual in lake herrings from lakes of the size of those listed above. Usually in inland lakes of this size, the lake herrings do not attain a length of more than eight or ten inches. However, we have two specimens from Meach lake and these are 14 and $14 \mathrm{r} / 2$ inches in length respectively.

That lake herring occur in the Ottawa river is indicated by the fact that 250 pounds of "herring" is included in the catch in the counties of Prescott, Russell and Carleton in 1902.

\section{Atlantic Salmon. Salmo salar Linnaeus.}

The only suggestion of the occurrence of the Atlantic salmon in the Ottawa region is contained in the following statement of Small (1883).

"Whether the common salmon (Salmo salar) was ever abundant in the Ottawa River prior to its sawdust and mill pollution is a question on which history is silent, as far as any authentic data can be given; but that they did frequent it there is no doubt, as the name Salmon River was retained by a small tributary near. Montebello, long after the native fish had abandoned it." 
Brown Trout. Salmo fario Linnaeus.

Sixteen hundred yearling brown trout were planted in the early autumn of 1937 in the Rideau below Hogs Back. A half-dozen adult brown trout exhibited at the Central Canada Exhibition, Ottawa, were also released in the Rideau above Hogs Back in 1935, 1936 and 1937.

They have also been planted in waters of the Seigniory Club near Montebello, Quebec, and in the Mississippi above the falls at Galetta. According to the reports of the Ontario Department of Game and Fisheries, the following numbers (presumably yearlings) were planted in the Mississippi : $1931,15,000 ; 1932,25,000 ; 1934,10,000$. In addition, in September, 1937, 1,500 fifteen months' old brown trout were planted in the Mississippi proper and 1,500 in the Ottawa river, South Branch, locally known as the "Snye". So far as known, no brown trout have survived to be taken by angling in the Mississippi.

\section{Rainbow Trout. Salmo gairdneri Richardson.}

Some years ago rainbow trout were planted in both Meach lake and lake Bernard. A few specimens were subsequently caught in each of these lakes (a five pound one in Meach lake) but they have now disappeared.

A half dozen adult rainbow trout exhibited at the Central Canada Exhibition, Ottawa, were released at the same time as the adult brown trout in the Rideau above Hogs Back in 1935, 1936 and 1937.

\section{Marston's Trout. Salvelinus marstoni (Garman).}

This interesting species was first described by Garman (1893) from specimens taken in Lac de Marbre (Marble lake) about twenty miles north of Ottawa on the east side of the Gatineau. Besides occurring in a number of lakes in this region, Marston's trout is known from lakes in the Lake St. John district, from Maskinonge county and from the vicinity of Rimouski.

$\mathrm{Mr}$. McCuaig lists the following lakes in the Ottawa region as containing Marston's trout: Marble, Ecluse (Big Dam), Bois Franc (Little Dam), Clair and Newcombe in Wakefield township, and Battle, Rhéaume, Sucker (Carrol) and Maskinonge in Templeton township.

Halkett (1914) recorded it from "Lac de Marbre near Ottawa; lakes of Laurentides Club in the Lake St. John region; Lac à Cassette, Rimouski county; and Lake Saccacomi and Red lakes, Maskinonge county; the above records probably right at the southern limits of its distribution and the centre of its distribution is much farther north." In 1912 Halkett had recorded specimens from a chain of three lakes in Maskinonge county. Chambers (1896) stated that specimens had frequently been taken in Lac des Îles. This is believed to be the lake of this name in Courcelles town- 
ship, Berthier county, due west of Decalonnes township, Maskinonge county, to which reference is made below. Mr. Rodd informs me that a specimen of Marston's trout was taken in June, 1934, in Lac La Croche north of St. Marguerite, Terrebonne county, P.Q. This specimen, which was 163/4 inches long, was mounted by the Canadian Pacific Railway Company.

Additional details of distribution are given by Evermann and Goldsborough (1907) as follows, "Lake Saccacomi and Red lakes (township of St. Alexis des Monts, Maskinonge County, Quebec) (John W. Titcomb, Coll. 1901); Decalonnes township, Quebec (specimen received by the U.S. National Museum in 1886 from Eugene Blackford); Lake Tourille, headwaters of St. Anne River, Province of Quebec (specimen received by U.S. National Museum in 1899 from Graham H. Harris); lake in Chernier township, Rimouski County, Province of Quebec (2 specimens received in 1896 by U.S. National Museum from Department of Crown Lands) (Evermann \& Kendall 1902)." Lac Casette is in Chenier township, Rimouski county, and is probably the lake referred to in this reference.

Marston's trout is probably more closely related to the circumpolar alpine char than it is to either the lake trout or the speckled trout. Like the lake trout, it has a deeply forked tail, but its back is uniformly coloured, lacking the dorsal spots of the lake trout and the vermiculations of the speckled trout In the spawning season the belly is a brilliant red. At this time the spots on the sides are orange with a crimson centre; at other seasons they are lighter coloured. It is a much more slender fish than the speckled trout. Chambers (1896) says, "a pound fish of this variety is nearly a third longer than a brook trout of the same weight in good condition but not more than half of the circumference." In summer it descends to the deeper water but in spring and fall may be taken on the fly. Chambers (loc. cit.) describes its behaviour in taking the fly as follows, "when the Marston trout takes the fly, it does not spring from almost immediately below it, as the brook trout seem to do, but rushes at it with a rapid dart, often for some distance along the top of the water, ... It leaps repeatedly out of the water when hooked and makes a desperate fight, its rapid motions being apparently due to its slender shape and graceful form."

For a time Marston's trout was propagated in limited numbers at the St. Alexis Hatchery, St. Alexis des Monts, not far from St. Paulin, Maskinonge county, Quebec. This hatchery was built and operated for a few years by C. H. Simpson of New York. In 1904 it was turned over to the federal Department of Fisheries. Efforts to collect eggs met with very limited success. Those collected were taken towards the end of the spawning season of the speckled trout of the district but not later than the end of October or the early part of November. Chambers (1896) is 
authority for the statement that this trout spawns later in the season than the speckled trout, probably in December or January.

The Annual Reports of the Department of Fisheries show the following distributions of Marston's trout in waters in which they were not previously reported. The waters in which these were placed are not listed.

1906, Mont Tremblant Hatchery, waters of the district, 55,000 fry.

1913, Lake Lester Hatchery, Nigar river, 750 fingerlings; Tompobia river, 750 fingerlings.

No records are known which would indicate that any of these transplanted Marston's trout have survived in waters to which they were not native.

Since Marston's trout is distinct from both the lake trout and speckled trout and is found in relatively few waters, as compared with these widely distributed species, every effort should be made to protect it. It is unfortunate that bass have been introduced into a number of lakes to which Marston's trout are native including Marble (the type locality), Ecluse (Big Dam), Bois Franc (Little Dam) and Newcombe. Mr. McCuaig is my authority for the statement that this unique trout is disappearing rapidly in Marble, Ecluse, Bois Franc, Clair and Newcombe lakes, due, he believes, to bass and illegal taking by nets. The necessity of giving Marston's trout every possible protection against extermination cannot be too strongly urged.

\section{Eastern Speckled Trout. Salvelimus fontinalis (Mitchill).}

Speckled trout are found or originally occurred in almost all the smaller lakes and many of the streams in the Laurentian country north of Ottawa. Small (1883) said they were, "well-known in the lakes and small rapid streams of the Laurentian mountains. . . . No trout are found in the waters south of the Ottawa, east of the Chats, where the Laurentides cross the river, whilst above that they abound in the streams on both sides. I have as my authority the late Dr. Van Cortlandt for stating that though they have been placed in streams on the south shore, they never lived there anytime."

Mr. McCuaig is my authority for the following list of speckled trout waters. West of the Gatineau: Lakes Curley, Ireland, Ramsay, Taylor, Lusk, Kingsmere, Kelly, Sandy, Philippe, Harrington, Meach and Fortune, also the upper waters of Mohr creek, and Chelsea brook. Between the Gatineau and Lièvre rivers: Lakes Charbonneau, Spectacles, Tenpenny, Forked, Girard, McGlashan, Cave, Indian, St. Charles, St. Germain, Waters, McGeary, Edges, Benoit, McNab, Fennock, Maskinonge, Clair, Noir and Gilmour, also the upper waters of Blackburn creek, Wilson brook, Mullin creek, Ruis Pelissier, and Petite Rivière Blanche. 
Halkett (1906A) recorded it from Pickanock near Gracefield and Lake Pembina, Lièvre river, P.Q.

The commercial catch indicated as trout in the records of the Department of Fisheries, probalsly inclurled speckled trout, particularly in the early years.

The sale of speckled trout was prohibited in Ontario after 1900, but a similar prohibition did not come into force on the (Duebec side until about 1928.

\section{Lake Trout. Cristivomer namaycush (Walbaum).}

The lake trout is native to most of the larger and deeper lakes of the Laurentian country north of the Ottawa.

Small (1883) reported it, "in most of the larger lakes in Ottawa and I'ontiac counties, and occasionally in the Lièvre and Gatineau, but always near the outlet of a lake... its average full weight in these waters is from 8 to 12 lbs. One was brought into Buckingham by some Indians a few years ago, which weighed close to 30 lbs." Van Cortlandt (1865) reported that a specimen caught that summer in Meach's lake weighed 23 pounds.

Referring to the practice of spearing lake trout in the fall when the fish come on the shallows to spawn, Small says, "I have known of parties going up to Whitefish Lake on the Lièvre for that purpose who returned with several barrels as their spoil."

Mr. McCuaig gives the following list of lakes containing lake trout, into which small-mouth black bass have been introduced: Thorne, Philippe, Harrington, Meach, Gauvreau, Wakefield, McArthur (Dowler), Grand, McGregor, Blanche, Long and Bernard.

Other lakes within thirty miles of Ottawa in which lake trout occur include Sheridan, McFee and Dodds.

In 1865 it was reported by Van Cortlandt that "every lake of any size, whether in Wakefield, Eardly, Hull, Templeton, Buckingham and elsewhere in Eastern Canada, and speaking from what I know, the great Opeongo lake in Canada West, is not only not wanting, but literally teem with them."

Van Cortlandt had a very low opinion of the lake trout. "In the first place, they occupy the deepest portions of the lake only, and seldom bite at a bait, whether natural or artificial, except at particular seasons, when they are taken with the greatest ease in very large numbers, and although they afford considerable sport to the angler, withal, when captured, they are scarcely worth the trouble of removing. The colour of their flesh is much lighter than that of the brook trout, and in many instances perfectly white when cooked, whilst in flavour it is absolutely insipid... when they take it into their heads to bite they may be captured almost as fast as 
the angler can cast his line, and take greedily at almost any bait between a piece of pork and a shred of red flannel. The latter end of October and November are the periods at which this fish takes bait best, but they are captured through the ice during the winter in large numbers."

Many fishermen believe that there are two or more kinds of lake trout, to which such names as grey trout, salmon trout, etc., are applied. Lake trout vary greatly in the size to which they grow, coloration, form, and colour of flesh, but none of these differences are believed to represent different species. In general, trout grow to a larger size in large lakes than in small ones, although exceptions from this rule occur. The reason for this difference is not understood but it is believed to result, in part at least, from the kind and amount of food available. In lakes in which lake herrings are found, the trout which feed on them usually grow to a larger size than in lakes in which they must live on much smaller organisms. The colour of lake trout varies from very light greenish or greyish to almost black. Some of these differences are also believed to be due to the character of the water in which they live. Dark trout are usually found in brownish water. The colour of the flesh varies from a pale ivory colour to deep pink. These differences are probably determined partly by heredity and partly by environment. Some trout are probably by nature lighter in flesh colour than others. On the other hand, it is probable that the kind and amount of food eaten also influences flesh colour. It has been suggested that an abundance of crustacean food will produce pink-fleshed trout.

The lake trout was formerly of considerable importance as a commercial species particularly in the Gatineau district as shown by the following selection of records from the reports of the Department of Marine and Fisheries. The area for which reports are given vary from time to time in these reports as indicated.

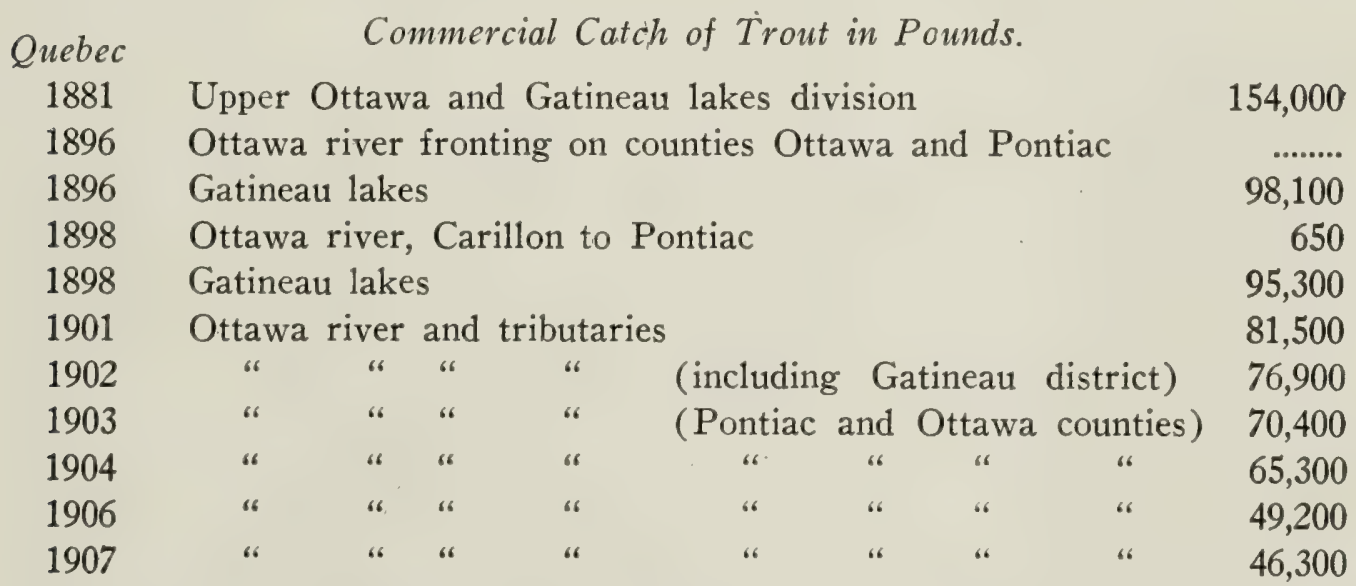

For the years 1908 to 1916 inclusive, the catch for the Ottawa district is not given separately from other inland areas in the fisheries statistics. Since that date, the commercial catch of trout has been negligible. 
It is probake that speckled trout cntered into the catch, particularly in the early days. The reports merely indicate the catch as "trout".

The fisheries statistics indicate that trout were never taken in commercial quantities on the Ontario side in this area.

\section{Smelt. Osmerus mordax (Mitchill).}

The smelt is native in at least two lakes in the Gatineau district and two near Pembroke. Halkett (1906 C) has recorded that, "Whilst engaged in scme fisheries matters in the month of May, 1903, I found some specimens of the American smelt floating dead on the surface of the water of Lac des Isles, in the Gatineau district, P.Q. It is known that this species of fish exists landlocked in fresh water lakes of New Brunswick, Nova Scotia and in the state of Maine, but its occurrence in a lake so far away from the sea as Lac des Isles is perhaps worthy of mention. The specimens are dwarfed and perhaps may be regarded as a subspecies; otherwise the external characters appear to agree with the ordinary form of Osmerus mordax."

Native smelts also occur in Green lake (altitude 476 feet) in the Kazubazua region, and in Muskrat and Doré lakes near Pembroke (Dymond 1937).

Smelts normally live in the sea, entering fresh water only at spawning time, although in New Brunswick and Maine they are permanent residents of some fresh water lakes. It is suggested that their occurrence in this area is a relic of the marine invasion mentioned in discussing the shad.

Smelts were introduced into Meach lake to serve as food for lake trout. Half a million eggs were introduced in each of two successive years about 1924. A few specimens were subsequently reported, but the species is now believed to be extinct there. The smelts introduced were of the small variety from Lake Utopia, New Brunswick.

\section{Eel. Anguilla rostrata (Le Sueur).}

The eel is found in the Ottawa and many of its tributary waters. Small (1883) reported it as "abundant". It has been and still is a fish of some commercial importance. The catch on the Quebec side has always exceeded that on the Ontario side of the Ottawa, largely because more persons engage in commercial fishery on the Quebec side. For the years 1896 to 1898 inclusive, the catch in Prescott and Carleton counties was in the neighbourhood of seven to nine thousand pounds. Then it fell away to practically nothing for a time. Most of the subsequent reports do not list the Ottawa region separately from other inland districts so that for only a few years, 1920 to 1922 , is it possible to get an idea of the extent of the catch in this area. For 1920, 1921 and 1922, the catch in the counties of Prescott, 
Russell, Carleton and Renfrew was 2,650, 3,964 and 2,049 pounds respectively.

The following selection from the Quebec records will indicate the extent of the catch at various periods.

Commercial Catch of Eels in Pounds.

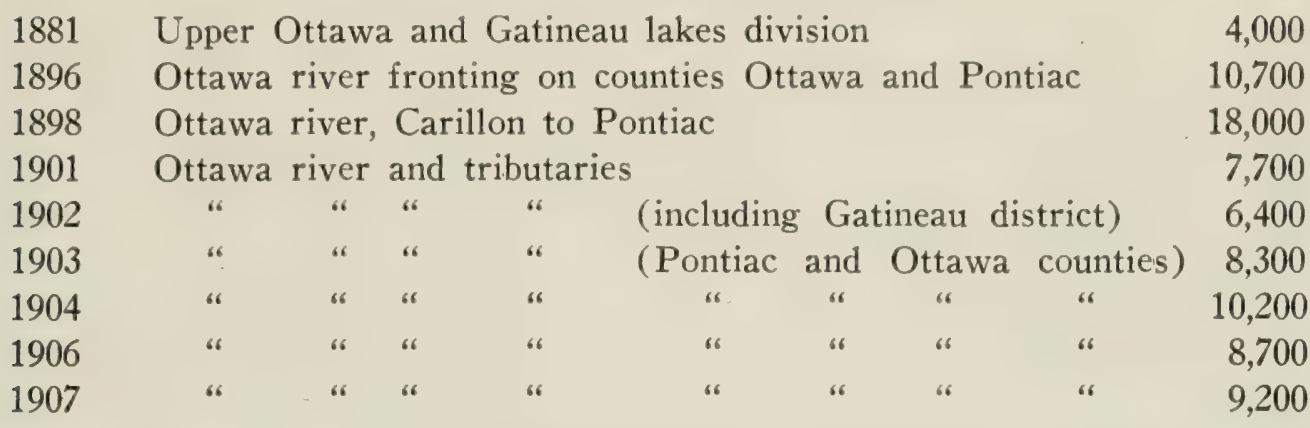

For the years 1908 to 1916 inclusive, the catch for the Ottawa district is not given separately from other inland areas. From 1917 to 1929, the catch fluctuated between 800 and 2,000 lbs. a year. Begining in 1930, there was a considerable increase in the eels taken in Hull, Labelle and Pontiac counties, as indicated by the following returns.

\begin{tabular}{|c|c|c|c|}
\hline 1930 & 7,400 lbs. & 1934 & $18,300 \mathrm{lbs}$ \\
\hline 1931 & 10,200 “ & 1935 & 17,300 “ \\
\hline 1932 & 18,800 “ & 1936 & 17,200 “ \\
\hline 1933 & 35,600 " " & 1937 & 9,000 " \\
\hline
\end{tabular}

Quillback. Carpiodes cyprinus (Le Sueur).

The finding of this member of the sucker family in the Ottawa was a surprise, since it had previously been known in Ontario only from Lake Erie. It is true that Small (1883) recorded, "The long-finned Sucker (Carpiodes cyprinus) . . . is not uncommon", but until we took a specimen in Green's creek, five miles east of Ottawa, Small's record was considered an error.

Is it possible that the following reference by Lemieux (1906) also refers to this species: "a small carp or sucker was discovered in the month of May in Morin's creek . . . In the past, no other fish than trout had been noticed in those lakes."

Northern Sucker: Sturgeon-nosed Sucker. Catostomus catostomus (Forster).

This sucker lives in the deeper waters of lakes. Mr. McCuaig reports it from lake Deschenes and similar lake-like expansions of the Ottawa. No specimens were secured during our survey of the region but this is not surprising, since the species is not taken in seining. Except when it resorts to cool streams to spawn, it is only taken in nets set in deep water. 
Although the long-nosed sucker was formerly known as Catostomus longirostris, it is rery doubtful if the following records of Small properly refer to the present species. In 1865 Small recorded Catostomus longirostris as "very abundant in all the streams of Canarla, where it is sometimes known as the Brook Sucker." In his account of the fishes of the Ottawa region, he recorded the same species as follows (Small 1883), "The Longnosed Sucker ( $C$. Longirostris) is a smaller fish seldom exceeding 5 or 6 inches, frecuenting the smaller streams, and is sometimes called the brook sucker (local name). It is very useful in an aquarium, where it acts as a scavenger, clearing up the refuse of other fishes. A curious habit it possesses is drawing in by suction a small portion of fine clean sand from the bottom and transporting it to another part of the aquarium where it deposits it by blowing it out and then returning for more. The horned Sucker (a variety) is found in our rivers, but it is not so abundant as the other species. It has a number of tubercles on its head (hence its name) the use of which is not apparent, but which are thought to be merely a sexual distinction." As already indicated, the northern sucker is not found in brooks as described by Small. The fish he identified as a long-nosed sucker was probably the long-nosed dace which is found in rapid streams and superficially resembles a sucker. The male has tubercles on his head at spawning time.

\section{Common Sucker. Catostomus commersonii (Lacépède).}

This sucker is a common fish in the waters of the Ottawa region. The adults live in the larger rivers, resorting to small streams in spring to spawn. Most of our specimens are young. We have them from the Ottawa river at Graham Bay; the Rideau river near the mouth of Black Rapids creek, at Billing's Bridge and at Hogs Back; Walt's creek near Connaught Rifle Ranges, Ottawa; Green's creek, five miles east of Ottawa; creek at Graham Bay station; Black Rapids creek; tributaries of the Jock river north of Fallowfield and two miles southwest of Richmond; Brassill's creek; north and south branches of Mud creek; Shirley creek near Strathearne; drainage ditch and Bear creek near Carlsbad Springs; McEwen's creek near Ramsayville; a creek five miles west of Cumberland; also in Constance lake; and on the Quebec side in Ramsay lake near Masham Mills; Blanche river, Jean d'Arc and Petite Rivière Blanche.

Small (1883) reported "the common sucker (Catostomus commersonii) attains a weight of from 3 to 4 pounds but its flesh is soft. It is one of the first fish that can be caught in the spring." Varieties were recognized as follows, "The rock sucker (a variety) has a firm flesh, and is freer from small bones. It is found in the shallows of the Rideau and Ottawa and in the Gatineau and attains a weight of 5 or 6 pounds. The pale sucker (a 
variety) runs up the sluggish streams from the larger rivers as soon as the thaw sets in in spring, but is insipid."

Mr. McCuaig says this sucker is usually known locally as the "Black Sucker."

Silver Mullet: White-nosed Red Horse. Moxostoma anisurum (Rafinesque).

We have several young of this species taken at mouth of Still creek, in Graham Bay, Ottawa river; at Mooney's Bay and Hogs Back, Rideau river and in a tributary of the South Nation river one mile southeast of Mountain, Dundas county.

Adults no doubt occur in the Ottawa and Rideau rivers, running into smaller streams in spring to spawn. This is probably the species referred to by Small (1883) under the name Moxostoma macrolepidotum. He described it as, "a large-scaled sucker-taken in the Ottawa, and attains a weight of 7 or 8 lbs."

Northern Redhorse: Short-headed Redhorse. Moxostoma lesueurii

(Richardson).

We have specimens of this redhorse only from the Rideau,-at Hogs Back, Mooney's bay and one mile above Black Rapids.

This and the preceding species occur farther north than any others of the genus, the present species, however, being the more northerly of the two.

There is a considerable difference in the length of head in the two species. In this one the head makes up 18 to 22 per cent. of the length measured to the base of the tail fin, whereas in $M$. anisurum it constitutes 24 to 30 per cent. of the length.

"Red Sucker" is the local name of this species.

Long-nosed Dace. Rhinichthys cataractae (Cuvier and Valenciennes).

The long-nosed dace is found in rapid water flowing over stones. Our only specimens are from the Rideau river near Billing's Bridge.

\section{Fall Fish: Chub. Leucosomus corporalis (Mitchill).}

One of the most interesting of the non-game fishes of the Ottawa region is the fallfish. It is often called chub, a name given in other parts of Ontario to its near relative Semotilus atromaculatus. Silver chub is still another name for this fish. The fallfish is the largest member of the family Cyprinidae which includes the chubs, shiners, dace and the fishes properly called minnows. It reaches a length of 15 to 18 inches.

In Ontario the fallfish is confined to eastern counties and the Ottawa 
valley. In the latter area it extends into Algonquin Park as far as the height of land between the Ottawa river and Georgian bay drainages. In the Ottawa area it is more common on the Quebec side since, as its name suggests, it frepuents edldies at the foot of falls and rapids, but it is found also in lakes. We have specimens from lake Bernard, the Gatineau river at Farm Point, Blanche river at Jean d'Arc and on the Ontario side from the Rideau river at Billing's Bridge and the south branch of the Castor river, one mile east of Vernon, Carleton county. Small (1883) called it the Roach Dace and said it was "abundant in the rapids of all our rivers where it affords good sport, taking equally well a worm, a fly or a grasshopper. Its average full size is from 1 to $1 \frac{1}{2}$ lbs. in weight."

In spring fallfish cause some annoyance to trout anglers by ti, ing their baits and lures; often several fallfish are hooked for each trout taken. Later in the season they provide a certain amount of sport because of their readiness to bite a variety of baits, one of the favourite being dough mixed with cotton batting to make it stay on the hook. Where the water is cold the flesh is firm and well flavoured. They are sometimes eaten by persons who are under the impression that they are some kind of trout.

\section{Creek Chub: Horned Dace. Semotilus atromaculatus (Mitchill).}

The creek chub is a common fish of the smaller streams. It was taken in a creek near Graham Bay station; Green creek, five miles east of Ottawa; drainage ditch and Bear creek near Carlsbad Springs; McEwen's creek near Ramsayville; a creek five miles west of Cumberland; Brassill's creek; Nichol's creek; a tributary of the Jock river, two miles southwest of Richmond; north and south branches of the Castor river also in McGregor lake; in Petite Rivière Blanche; the Gatineau river at Farm Point, Quebec, and in Ramsay lake near Masham Mills, P.Q.

This is probably the species which Small (1883) referred to as the small chub, in contrast to the large chub (Leucosomus corporalis). He was in error in identifying it as Erimyzon sucetta. He said it was "common in rapid dashing streams especially in the south side of the Ottawa, and in the early spring is abundant in the waste water stream from Hartwell's Locks, and in many of our small rapid streams."

Northern Dace. Margariscus margarita nachtriebi (Cox).

This is a minnow of rather boggy waters. We found it in a creek at Graham Bay station; in Black Rapids creek; tributary of Jock river two miles southwest of Richmond and in Brassill's creek.

Black-chin Shiner. Notropis heterodon (Cope).

This small shiner was found only in Steven creek, one mile northwest of North Gower. 
Muskoka Minnow. Notropis heterolepis Eigenmann \& Eigenmann.

This minnow is widely distributed in Ontario, being found most conmonly in small lakes and in streams of little current, particularly over a muddy bottom. Our specimens are from Graham bay, Ottawa river; a backwater of the Rideau above Black Rapids; a tributary of the South Nation river, one mile southeast of Mountain; the middle and south branches of the Castor river; Meach lake, and Ramsay lake near Masham Mills, P.Q.

Sand Shiner. Notropis deliciosus (Girard).

This small shiner was taken only in Graham bay, Ottawa river.

Mimic Shiner. Notropis volucellus (Cope).

The mimic shiner, which is very similar in appearance to the sand shiner, was found in a tributary of the South Nation river, one mile southeast of Mountain; in the south branch of Castor river, one mile east of Vernon, and in the Blanche river at Jean d'Arc, Quebec.

\section{Spot-tail Minnow. Notropis hudsonius (Clinton).}

This is a minnow of the larger rivers and lakes. It was found in the Ottawa river at Graham bay and in the Rideau river at Hogs Back and one mile above Black Rapids.

Lake Shiner. Notropis atherinoides Rafinesque.

Although we have no specimens from the Ottawa region, this minnow undoubtedly occurs in the Ottawa river, since it is characteristic of larger rivers and lakes. It is probable that this is the species referred to by Small (1883) as follows, "The shining dace (Minnilus rubellus), known also as the white minnow is abundant, and its young or small fry are the fish which throng the edge of wharves, and shallow water below locks, where they can be taken abundantly with the scoop net." $N$. rubellus is very similar in appearance to $N$. atherinoides. The former, however, frequents swift water, whereas it is a habit of atherinoides to swarm about wharves. Forbes and Richardson (1908) report that "among our collections from the smaller lakes of northeastern Illinois we have not obtained a single specimen of this species, while the waters of Lake Michigan, but a few miles away, were swarming with them along the shore, and especially about the wharfs."

Rosy-faced Shiner. Notropis rubellus (Agassiz).

This shiner, which superficially resembles $N$. atherinoides, is found in swift waters. We took it in such a situation in the Blanche river at Jean d'Arc, P.Q. 
Creek Shiner. Notropis cormutus (Mitchill).

The creek shiner is one of the most common minnows in many parts of Ontario. We found it in Graham bay, Ottawa river; Rideau river at Billing's Bridge; Green creek, five miles east of Ottawa; Brassill's creek; tributary of South Nation river, one mile southeast of Mountain; drainage ditch near Carlsbad Springs; Steven creek near North Gower; south branch Mud creek, four miles north of North Gower; middle and south branches of the Castor river and King's creek. On the Quebec side, we took it in Blanche river, Jean d'Arc, Petite Rivière Blanche and McGregor lake.

Small (1883) said "frequents deep holes or pot-holes of rapid streams, associated with brook trout ... abundant in the Gatineau, Blanche and all the tributaries of large rivers. It is plentiful in the pools of the Chelsea trout stream."

\section{Golden Shiner. Notemigonus crysoleucas (Mitchill).}

The golden shiner is found in weedy situations in lakes, ponds and streams. Our specimens are from a backwater of the Rideau river above Black Rapids; Graham bay, Ottawa river; IValt's creek near Connaught Rifle Ranges, Ottawa; Jock river, three miles northeast of Richmond; tributary of South Nation river, one mile southeast of Mountain; Nichol's creek, a tributary of the Jock; south branch of Cranberry creek near North Gower; Steven creek, one mile northwest of North Gower; middle and south branches of Castor river and Constance lake.

Small (1883) reported it "in all our streams in calm water, but it is not very abundant."

Brassy Minnow. Hybognathus hankinsoni Hubbs.

The brassy minnow was taken in large numbers in Brassill's creek, Carleton county; and in Ramsay lake, near Masham Mills, P.Q. It lives in cooler water than $H$. regius, commonly in little bog creeks and bog lakes.

\section{Eastern Brassy Minnow. - Hybognathus regius Girard.}

This is an Atlantic coast species, whose occurrence in a few localities in the Ottawa area is another example of the penetration into this region of forms whose general distribution is farther east. It lives in larger waters than $H$. hankinsoni, having been taken in the Ottawa river at Rockland; at the mouth of Green creek, five miles east of Ottawa; and in Petite Rivière Blanche, Quebec. 
Red-bellied Dace. Chrosomus eos Cope.

This small minnow is found in rather sluggish, acid waters. We have specimens from a tributary of the Jock river, two miles southwest of Richmond; from Brassill's creek and from Ramsay lake near Masham Mills, P.Q. It seems likely that the fish called striped minnow and black-nosed dace by Small (1883) was the red-bellied dace. This is indicated by the fact that the fish he described had a "rich orange colouring on its belly." This is a characteristic of the red-bellied dace before it acquires the red belly at spawning time. Small adds "this is so sharply marked as to have given rise to the idea of the existence of a different species to which the name red-bellied minnow (Chrosomus erythrogaster) has been given." Elsewhere he says "Now I think this fish (the red-bellied dace) is only a variety of the black-nosed dace (Rhinichthys atronasus)." It seems quite certain that the latter fish does not occur in the Ottawa region. It has never been found in eastern Ontario, although extensive collections have been made in that area.

The anonymous writer (Dr. Van Cortlandt?) of the list of 1865 was of the opinion that both black-nosed dace and red-bellied dace occurred together in "Minnow Lake", Hull, but as suggested above, it is probable that the two forms were red-bellied dace at different stages of sexual maturity. The name striped minnow no doubt was suggested by the two dark longitudinal lines, characteristic of the red-bellied dace.

The red-bellied dace of Ontario was until recently regarded as belonging to the species $C$. erythrogaster but this is now believed to be a southern species, the northern species being $C$. eos.

\section{Blunt-nose Minnow. Hyborhynchus notatus (Rafinesque).}

A widely distributed minnow. In the Ottawa region it has been taken in the Rideau river at Billing's Bridge, at Hogs Back, near the mouth of Black Rapids creek and one mile above Black Rapids; Green creek, five miles east of Ottawa; Walt's creek near Connaught Rifle Ranges, Ottawa; tributary of South Nation river one mile southeast of Mountain; King's creek; south branch Castor river; Constance lake; and on the Quebec side in Meach lake; McGregor lake and Blanche river, Jean d'Arc.

\section{Blackhead Minnow, Fathead Minnow. Pimephales promelas}

\section{Rafinesque.}

This minnow is found in sluggish waters, especially those of a boggy nature. It was found in Brassill's creek; in a tributary of the Jock river, two miles southwest of Richmond; in Black Rapids creek; in a creek five miles west of Cumberland and in Ramsay lake near Masham Mills, P.Q. 


\section{Channel Catfish. Ictalurus punctatus (Rafinesque).}

The channel catfish, in contrast to the bullhead, prefers clear waters flowing over rocky bottoms. In such situations it is found in the lower Great I akes region and southward in the Mississippi valley to the Gulf of Mexico. It occurs in the ()ttawa as far as lake Expanse and in the Gatineau as far as lake Baskatong which is probably its most northerly point of occurrence in the east.

Small (1883) said it was "met with in the Ottawa river, in the deepest parts or channel, and specimens of it may occasionally be seen in our market of ten lbs. upwards, but a fish of over $4 \mathrm{lbs}$. weight is a large one for these waters."

The channel catfish is an excellent food fish and is still sold on the Ottawa market, specimens having been purchased there on September 1, 1937.

The catch of this species is not always separated from that of the bullhead in the reports of the Department of Marine and Fisheries but for a few years in the Quebec reports the figures are given separately. These are quoted in the discussion of the next species. From these it is seen that the catch of the channel cat usually exceeded that of bullheads.

\section{Common Bullhead. Ameiurus nebulosus (Le Sueur).}

The bullhead is common in waters with a muddy bottom. We have specimens from the Rideau river at Hogs Back, near the mouth of Black Rapids creek and one milé above Black Rapids; Walt's creek near Connaught Rifle Ranges, Ottawa; in a tributary of the South Nation river, one mile southeast of Mountain; King's creek, Carleton county; middle and south branches of the Castor river, near Metcalfe and Vernon respectively; in drainage creeks three miles south of Navan and four miles east of Carlsbad Springs and in McGregor lake and the Gatineau river. It is also known to occur in the Ottawa river. Halkett (1906 A \& B) had it from the Rideau canal, Gilmour creek and Kinburn. Small (1883) reported it as "very common in any water with a muddy bottom."

Mr. McCuaig writes, "The fish are plentiful in every tributary of the Ottawa and are taken to the source of these streams. Lakes that do not contain these fish are very difficult to find. They provide the fish supply to the French population of the Ottawa valley. They love them and prefer them to speckled trout. They catch them in marshes and shallow bays by the boat load."

In the reports of the Department of Marine and Fisheries the catch of bullheads is often, apparently, combined with that of the channel catfish but for a number of years the catches were separated in the Quebec figures 
as indicated below. Records for certain years have been selected to indicate the extent of the fishery.

Commercial Catch of Catfish in Pounds.

\begin{tabular}{|c|c|c|c|c|c|}
\hline Intario & & & & & \\
\hline 1896 & Prescott & and Carl & eton & & 27,250 \\
\hline 1898 & " & “ & & & 41,100 \\
\hline 1901 & Prescott, & Russell & and Carleton & & 2,300 \\
\hline 1902 & “ & “ & “ & & 7,600 \\
\hline 1903 & “ & " & “ & & 17,825 \\
\hline 1904 & “ & “ & “ & & 14,200 \\
\hline 1906 & " & “ & “ & & 7,600 \\
\hline 1907 & Prescott, & Russell, & Carleton and & Renfrew & 500 \\
\hline 1908 & ") & " & ". & " & 13,800 \\
\hline 1920 & “ & “ & “ & “ & 29,615 \\
\hline 1921 & “ & “ & “ & “ & 16,827 \\
\hline 1922 & “ & “ & “ $" ~ “$ & " & 11,848 \\
\hline
\end{tabular}

(Not given separately from other inland waters in subsequent reports.)

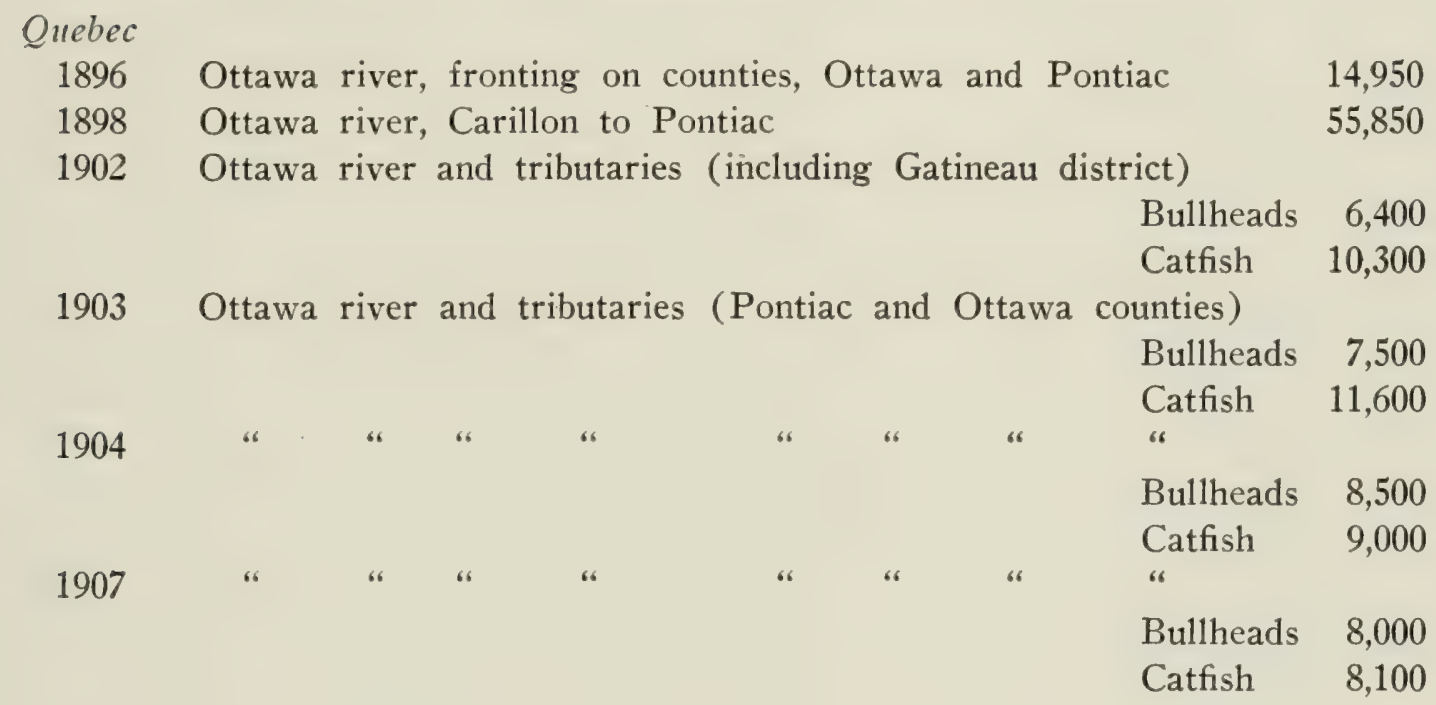

For the years 1908 to 1916 inclusive the catch for the Ottawa district is not given separately from other areas in the fisheries statistics. For recent years the catch has been recorded merely as "catfish". Following are the combined catches for the counties of Hull, Labelle and Pontiac.

\begin{tabular}{|c|c|c|c|}
\hline 1927 & 21,300 lbs. & 1932 & 43,200 lbs. \\
\hline 1928 & 22,300 “ & 1933 & 50,900 " \\
\hline 1929 & 18,300 & 1934 & 32,300 \\
\hline 1930 & 20,500 & 1935 & $33,500 "$ \\
\hline 1931 & 28,400 “ & 1936 & 33,300 \\
\hline & & 1937 & 19,000 " \\
\hline
\end{tabular}

Tadpole Cat. Schilbeodes gyrinus (Mitchill).

Two species of these small catfishes occur in Ontario, S. miurus in the lake Erie drainage and S. gyrimus eastward. It appears to prefer quiet, 
muddy waters rather than those with a rapid current. (Our specimens are from a muddy and weedy tributary of the South Nation river, one mile southeast of Mountain, Dundas county, and from the south branch of the Castor river, one mile east of Vernon, Carleton county.

\section{Mud Minnow. Umbra limi (Kirtland).}

The mud minnow is found in creeks and ponds, especially those with a mudkly bottom. It was taken in the creek at Graham bay station; in Black Rapids creek; Brassill's creek; Nichol's creek tributary to the Jock river and in another tributary of the Jock, two miles southwest of Richmond; in the south branch of Cranberry creek near North Gower; in Steven's creek and in the south branch of Mud creek, four miles north of North Gower. It was also found in a stream flowing into McGregor lake, Quebec.

Small (1883) reported it "in the clay pits near the Rideau River and in the lagoon east of the canal near Hogsback, as well as in small streams running into the Lièvre and Ottawa rivers."

Pike. Esox lucius Linnaeus.

The pike is found in abundance in the Ottawa and in most of its tributaries in the Ottawa region, including the Rideau, Jock, Carp, Mississippi, Nation, Gatineau, Blanche, Lievre, Rivière Petite Nation and Quyon.

We have specimens from Rideau river at Billing's Bridge, McEwen's creek near Ramsayville, Jock river and two of its tributaries, one near Fallowfield and the other Nichol's creek, and from the following creeks in Carleton county: King's creek, south branch Cranberry creek, north and south branches of Mud creek and the north branch of Castor river southwest of Greely. We also took young pike in McGregor's lake, P.Q.

Halkett (1906 A \& B) recorded the pike from Gilmour's Mills near Ottawa; Lac des Isles, Gatineau district, P.Q., and Shirley's bay. Small (1883) gives no definite records of the pike in the Ottawa region. Under the name Esox Reticulatus, he refers to the pike as "a well-known fish everywhere." He also says, "Another species, the northern pike (E.lucius) is met with here occasionally." Both these statements undoubtedly refer to the common pike.

Certain peculiarities in the distribution of pike north of the Ottawa are of interest in connection with the general problem of fish distribution. In some of the rivers, notably the Gatineau and Lievre, pike are found practically to their source; in others they are absent above the first high falls. For instance, pike are found in the lower reaches of Rivière Lapêche and Rivière Blanche (Templeton township) but are absent from Lac Lapêche and lakes above McGregor lake. Although pike now occur in McGregor lake, they were not found there until 1931. These originated from plant- 
ings made in 1927, when specimens were taken from the Ottawa river and planted in a small lake just north of McGregor. In September, 1936, a specimen weighing 25 pounds was taken by James Last in McGregor lake. Pike have also been introduced into Meach, Mahon and McLeod lakes.

Two close relatives of the pike, Esox vermiculatus and Esox niger, occur south and east of the Ottawa area. E. vermiculatus, commonly called Little Pickerel and Grass Pickerel, seldom grows over a foot in length or a pound in weight. It has been taken in a number of waters in Leeds county. E. niger, which is called Chain Pickerel and Eastern Pickerel, is said to reach a weight of four pounds. We have specimens from the vicinity of Sherbrooke, P.Q. There are no authentic records of the occurrence of either of these species in the Ottawa region. Careful inquiries have convinced me that the specimen identified as Esox niger, taken by $\mathrm{Mr}$. G. Scattergood in McGregor lake on September 12, 1935, was a common pike, Esox lucius. Mr. Scattergood's specimen, 36 inches in length and weighing 10 pounds, 10 ounces, was accepted as a world's record Esox niger.

There is great confusion in the use of the names pike and pickerel. Esox lucius is found in England and many parts of northern Europe and Asia. In England, it has long been called pike, and the early Englishspeaking settlers of North America naturally applied that name to the same species on this continent. "Pike" is therefore the logical name of Esox lucius. The word pickerel is the diminutive of pike and means literally "little pike". It is therefore the logical name of such species as Esox vermiculatus and Esox niger, close relatives of the pike, which never reach a large size. To apply the name pike, as many United States sportsmen do, or the name pickerel, as many Canadians do, to the pike-perch (Stizostedion vitreum) is entirely erroneous. There can be no serious objection to the use of the name pickerel for a small Esox lucius, and the name great northern pike to large specimens of the same species, provided it is realized that they both belong to the same species.

The pike has been of some commercial importance in this area, as indicated by the following records from the reports of the Department of Marine and Fisheries. The reports for 1875 give 15 barrels as the catch in the Madawaska and Lake des Chats region of Ontario. In these reports, the areas covered vary from period to period as indicated. The catch for certain years has been selected to indicate the extent of the fishery.

\section{Commercial Catch of Pike in Pounds.}

Ontario

1891 Ottawa river fronting on Prescott, Russell and Carleton counties and inland waters

1896 Prescott and Carleton counties

1898

9,500 


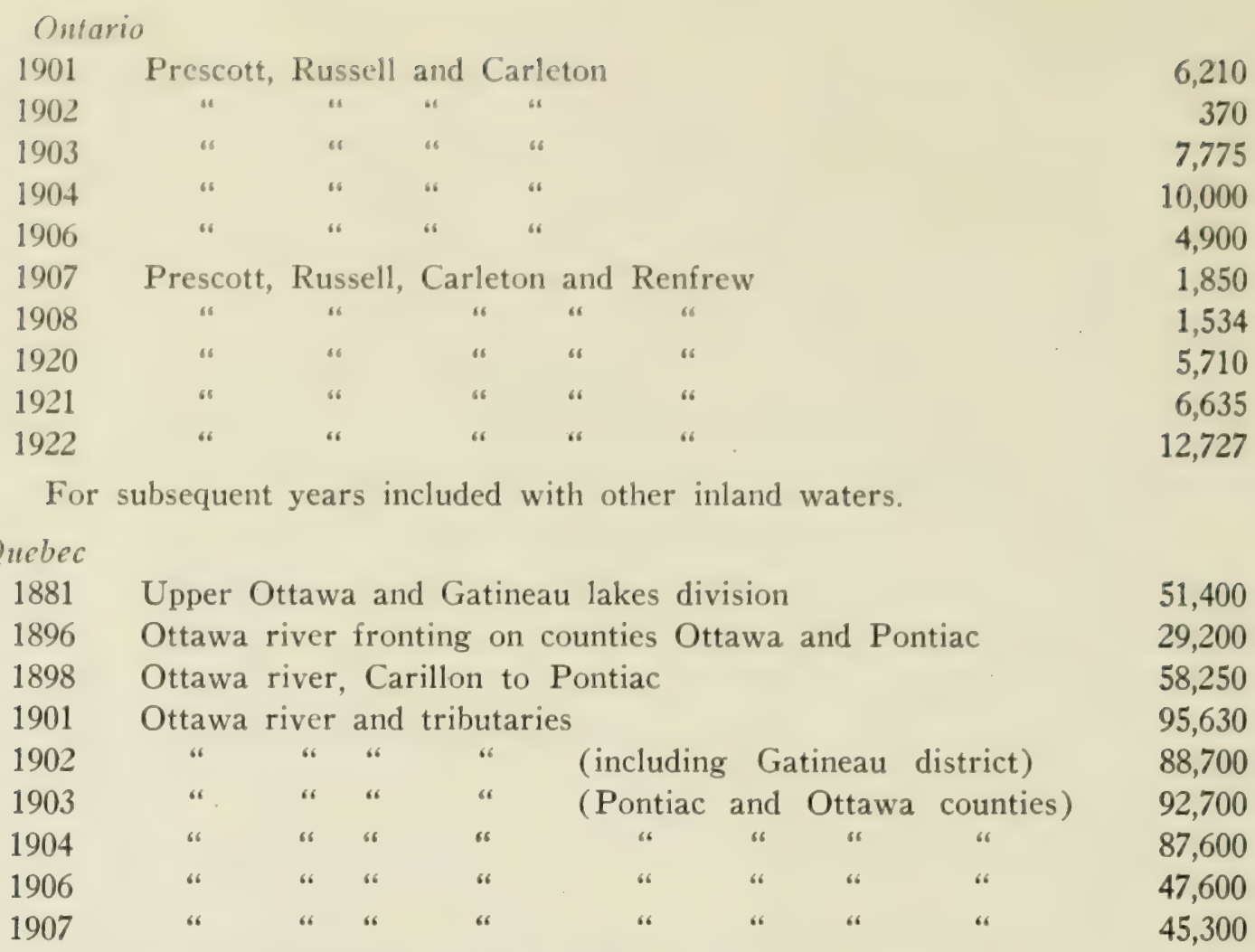

For the period 1908-1916, the catch for the Ottawa district is not listed separately from other inland districts. For 1918, the catch in the counties of Labelle, Wright and Pontiac was 3,300 lbs. and remained at approximately this level for several years. Mr. McCuaig informs me that on the Ottawa market since 1928, there has been offered for sale during the open season tons of pike every Thursday, and many times the quantity sold in Ottawa and Hull goes to Montreal. The following records for the counties of Hull, Labelle and Pontiac give some indication of the extent of the fishery.

\begin{tabular}{|c|c|c|c|}
\hline 1928 & 5,100 1bs. & 1933 & $25,600 \mathrm{lbs}$. \\
\hline 1929 & 6,200 “ & 1934 & 15,600 " \\
\hline 1930 & 6,600 & 1935 & 12,200 " \\
\hline 1931 & 7,200 & 1936 & 16,100 “ \\
\hline 1932 & 20,400 & 1937 & 20,000 \\
\hline
\end{tabular}

Maskinonge. Esox masquinongy Mitchill.

The maskinonge occurs in the Ottawa and Rideau rivers. In the Rideau it is not found south of Merrickville. In the Ottawa it is found as far as Les Joachim rapids and in the Petawawa river to Lake Traverse in Algonquin Park. Their occurrence in Dumoine river is due to a recent introduction. It is also said to occur in the Carp river. On the Quebec side, the maskinonge is found in Gilmour, Donaldson and Plumbago lakes in Templeton and Buckingham townships, Papineau county. 
Small (1883) said, "It is found in the Ottawa and Ridean Rivers, and in the Canal, and in the lakes connected with the Gatineau and Lievres rivers ... near the Quio is one of the best fishing grounds for this fish, but very large ones are taken in the Rideau. Mr. Lapointe tells me the largest maskinonge he has ever offered for sale was 42 lbs." A specimen weighing thirty-three and a half pounds taken in the Ottawa river opposite Clarence, September 9, 1865, is recorded in the Citizen for September 11, 1865. Small states that he had been informed that maskinonge from Rice lake had been planted in Campbell's bay, Ottawa river.

Halkett (1906A, 1907) had specimens from the Ottawa river at Britannia and lake Deschene. Montpetit (1897) recorded it as occurring from "Quebec to the upper Ottawa."

Maskinonge were formerly regarded as commercial fish and considerable quantities were caught and sold as indicated by the following statistics taken from the reports of the Department of Marine and Fisheries. It will be noticed that the areas for which the catch is given vary from period to period so that they are not directly comparable. In years when the catch in the Gatineau lakes is given separately from that of the Ottawa it will be seen that none is given for the former, indicating that the Ottawa supported most, if not all, of the commercial fishery for maskinonge. It will also be noticed that commercial fishing for maskinonge continued in Quebec for some years after it was discontinued in Ontario.

A selection has been made from the record of commercial catch for certain years to indicate the extent of the commercial fishery.

\begin{tabular}{|c|c|}
\hline \multirow{2}{*}{\multicolumn{2}{|c|}{ Ontario }} \\
\hline & \\
\hline 1875 & Madawaska river and Lake des Chats division \\
\hline 1886 & Prescott, Russell and Carleton \\
\hline 1891 & $\begin{array}{l}\text { Ottawa river fronting on Prescott, Russell and Carleton } \\
\text { counties and inland waters }\end{array}$ \\
\hline 1896 & Prescott and Carleton \\
\hline 1898 & " " " " \\
\hline 1900 & Prescott, Russell and Carleton \\
\hline 1901 & " “ \\
\hline 1902 & " $\quad$ " \\
\hline \multicolumn{2}{|l|}{ Quebec } \\
\hline 1881 & Upper Ottawa and Gatineau Lakes division \\
\hline 1886 & Upper Ottawa \\
\hline & Gatineau lakes \\
\hline 1891 & Upper Ottawa \\
\hline & Gatineau lakes \\
\hline 1896 & $\begin{array}{l}\text { Ottawa river fronting on counties Ottawa and Pontiac } \\
\text { Gatineau lakes }\end{array}$ \\
\hline
\end{tabular}

10 barrels $10,500 \mathrm{lbs}$.

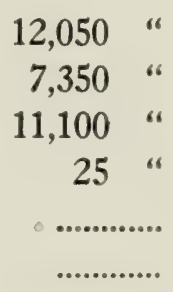

1,800 “

1,650 “

4,500 "

12,130 " 


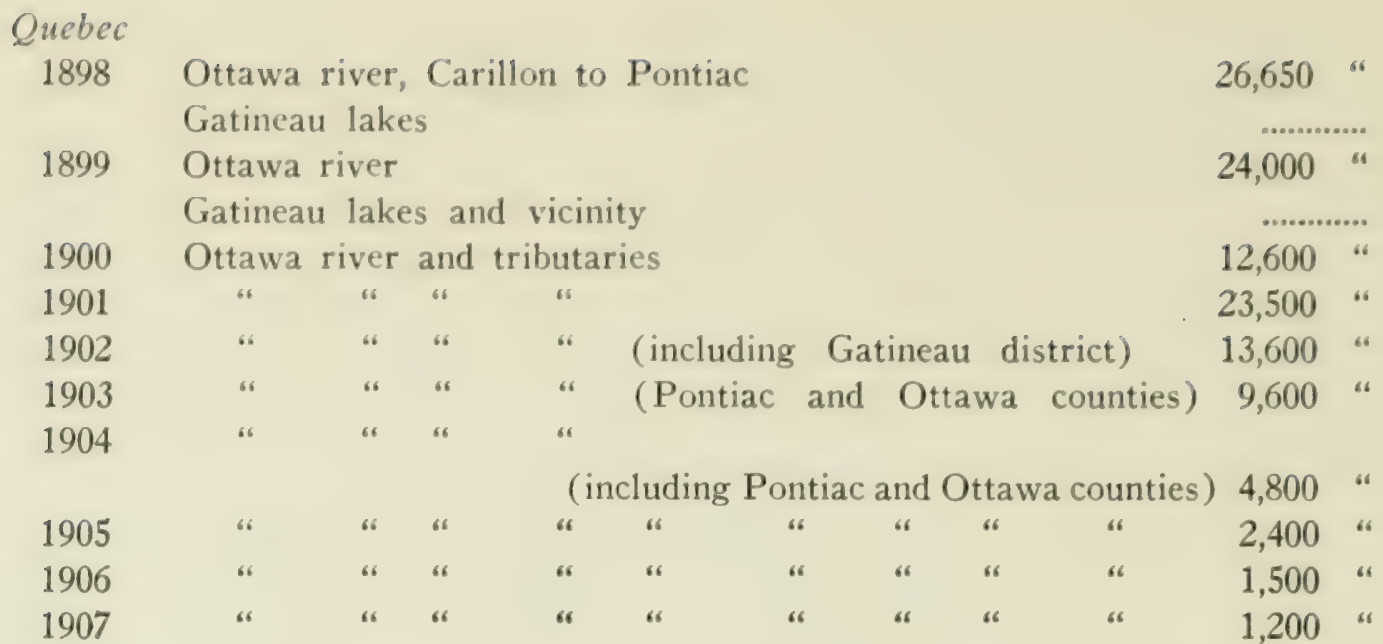

For the years 1908 to 1916 , the catch in the Ottawa district is not listed separately from that of other inland districts. From 1917 to 1925 inclusive, no maskinonge are recorded in the catch for this area. For the years 1926, 1927 and 1928, a catch of 100 lbs. is recorded each year in Labelle county. For the years 1927 to 1936 inclusive, a catch of several hundred pounds a year is reported for Pontiac county. Representative catches for this period are as follows: 1927, 200 lbs. ; 1930, 400 lbs.; 1932, 800 lbs. ; 1934, 1,800 lbs. ; 1936, 1,800 lbs. No maskinonge are reported for this region for 1937.

Killifish. Fundulus diaphanus menona Jordan \& Copeland.

Specimens of killifish were taken only in Constance lake, but Halkett (1906B) had it from Hull.

Trout Perch. Percopsis omisco-maycus (Walbaum).

The trout perch is usually found in the larger rivers and lakes but resorts to smaller streams in early summer to spawn. It was taken at the mouth of a small cold stream flowing into the Rideau river near Billing's Bridge and in the Petite Rivière Blanche in Quebec.

Common Perch. Perca flavescens (Mitchill).

A common fish in almost all waters. We have specimens from the Ottawa river at Graham bay and Hiawatha Park; from Rideau river near Black Rapids; in Black Rapids creek, one mile east of Merivale; in a creek at Graham Bay station; in Walt's creek near Connaught Rifle Ranges, Ottawa; in Constance lake, and on the Quebec side in Blanche river and McGregor lake. It is also said to occur in Meach lake, and in most of the lakes in the Laurentian country north of Ottawa.

Halkett (1906A) had perch from Lac des Isles in the Gatineau district. Small (1883) said it "abounds in both lake and river, pond and stream, 
varying considerably in size and colour, according to locality and food. Three pounds is the extreme weight I have heard of, but a one-pound perch is a large specimen ordinarily. A lake near Buckingham, known as Donaldson's Lake is full of very fine perch and of good quality."

Following are selections from the records of the commercial catch of perch taken from the reports of the Department of Marine and Fisheries. It will be noticed that the areas covered varied from period to period.

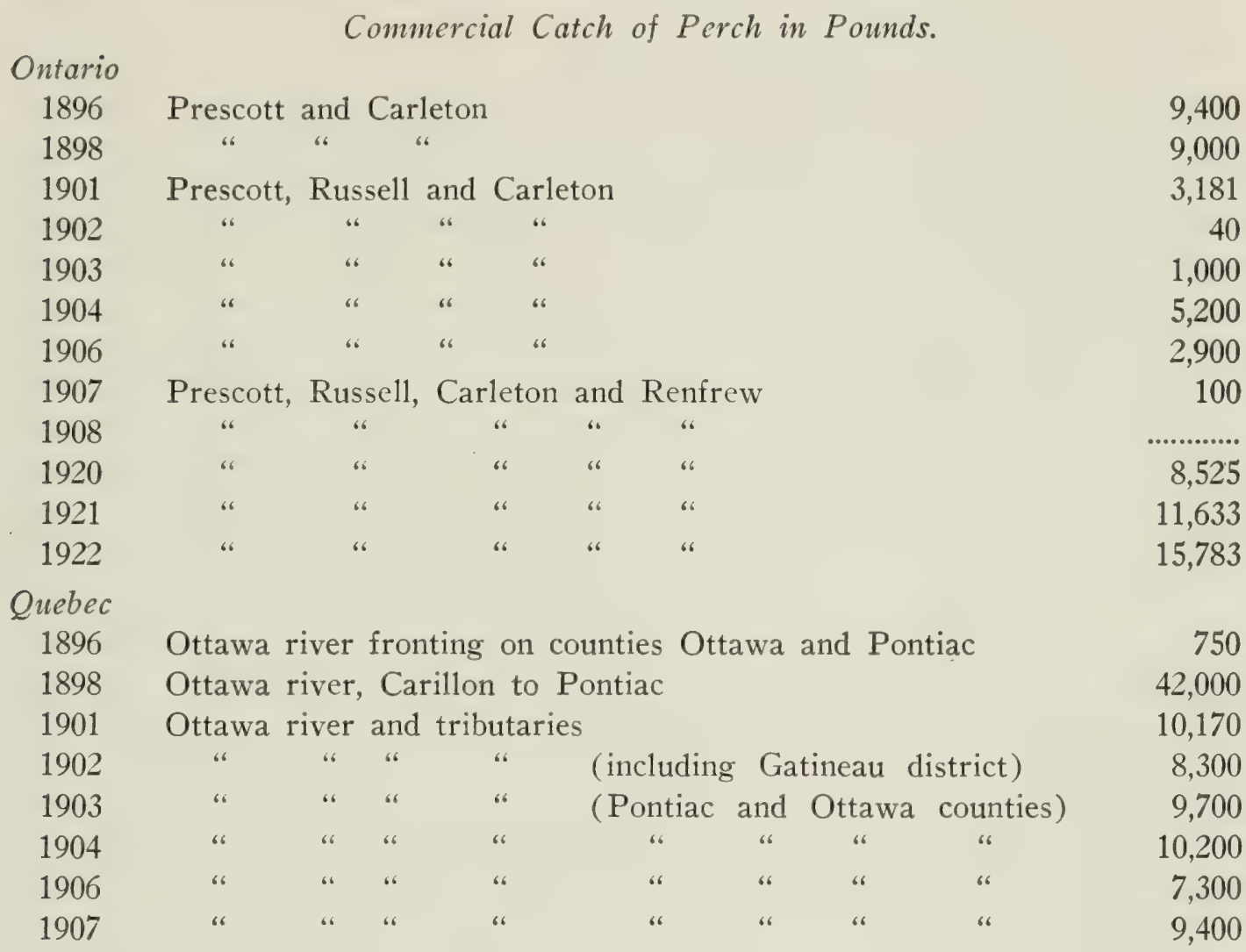

For the years 1908 to 1916 inclusive, the catch for the Ottawa district is not given separately from other inland areas in the fisheries statistics. In the following records for recent years, the entire catch was made in Labelle and Pontiac counties, except in 1936, when 2,000 1bs. were taken in Hull county.

$\begin{array}{rrrr}1928 & 4,800 \text { lbs. } & 1933 & 10,600 \text { lbs. } \\ 1929 & 7,800 \text { “ } & 1934 & 8,400 \text { “ } \\ 1930 & 7,700 \text { “ } & 1935 & 8,900 \text { “ } \\ 1931 & 6,800 \text { “ } & 1936 & 10,400 \text { “ } \\ 1932 & 8,700 \text { “ } & 1937 & 17,000 \text { “ }\end{array}$

Pike-perch; Doré; Yellow Pickerel. Stizostedion vitreum (Mitchill).

The pike-perch is not uncommon in the Ottawa region. Small (1883) said it was "abundant in our waters . . Large specimens reach from 8 to 10 lbs. weight, but 4 lbs. is an average size." 
In the first annual report of the Ontario Fisheries Branch for the year 1899, it is stated that pickerel weighing nearly seven pounds were to be had within three miles of the city of Ottawa.

We have specimens from the Rideau river at Billing's Bridge where good sized specimens are sometimes caught. They are also taken in the Ottawa and in the Catineau at least as far as Paskatong lake and dam. They are found in Bowman lake and the Lievre river below this point. The Picanoc, a tributary of the Gatineau, is said to be one of the best "pickerel" streams in the Gatineau valley.

Halkett (1906A) had it from Gilmour's Mills (on the Gatineau), P.Q. Small (1883) stated that he had been informed that dore from the Detroit river and from lake Huron had been placed in Campbell's bay, Ottawa river.

The objection to the names "pickerel" and "pike" commonly applied to this species in Canada and the United States respectively is discussed under the true pike, Esox lucius. As Stizostedion vitreum is a member of the perch family, the name pike-perch, which signifies pike-like perch, is an excellent one. The French-Canadian name doré, meaning "golden one", is also suitable.

Considerable quantities of pike-perch have been taken for commercial purposes principally in the Ottawa, Gatineau and Lievre rivers. In the reports of the Department of Marine and Fisheries from which these figures are taken the areas covered vary from period to period as indicated. The catch for certain years only, have been selected in order to show the extent of the fishery from period to period.

Commercial Catch of Pickerel in Pounds.

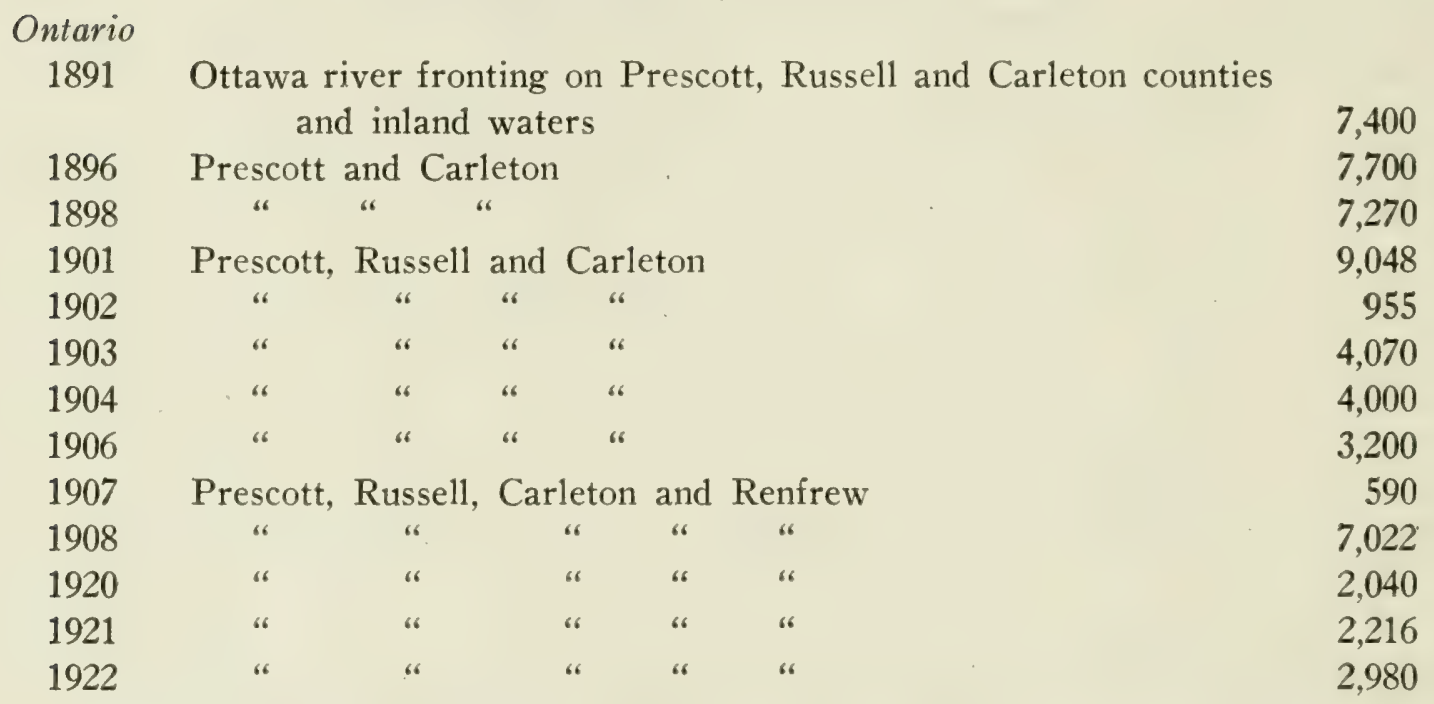

(Not given separately from other inland waters in subsequent reports.) 
1896 Ottawa river fronting on counties Ottawa and Pontiac 38,220

1896 Gatineau lakes $\quad 10,600$

1898 Ottawa river, Carillon to Pontiac $\quad 54,750$

$1898 \quad$ Gatineau lakes $\quad 12,750$

1901 Ottawa river and tributaries $\quad 41,000$

1902 " " " " " (including Gatineau district) 38,500

1903 " " " " " " (Pontiac and Ottawa counties) 33,500

1904 " " " " " " " " " " "

1906 " " "

1907 " 1906 "

For the years 1908 to 1916 inclusive, the catch for the Ottawa district is not given separately from other inland areas. The following records will indicate the trend of the catch in recent years in Hull, Labelle and Pontiac counties.

\begin{tabular}{|c|c|c|c|}
\hline 1929 & $3,500 \mathrm{lbs}$. & 1933 & 11,300 lbs. \\
\hline 1930 & 4,100 & 1934 & 8,500 \\
\hline 1931 & 5,100 “ & 1935 & 8,000 \\
\hline 1932 & 9,800 “ & 1936 & 7,500 “ \\
\hline & & 1937 & 5,000 “ \\
\hline
\end{tabular}

Sauger. Stizostedion canadense (Smith).

Both Small (1883) and Halkett (1907) record this species from the Ottawa region. Halkett (1907) reported a specimen from Gilmour's Mills, P.Q., near Ottawa. Small wrote "The Canadian Doré (S. Canadense) ranging from 1 to $4 \mathrm{lbs}$. with a few pale yellow spots below the lateral line, and the grey dore ( $S$. Griseum) of a greyer colour than the two preceding (i.e. S. Vitreum and $S$. Canadense) seldom exceeding a few inches in length, are found where the Common Doré exists but not so abundantly. They are met with in the Rideau, Ottawa, Lievres and Gatineau Rivers, the Grey Doré being plentiful in the Rideau River."

\section{Log Perch. Percina caprodes zebra (Agassiz).}

This, the largest of the darters, was found in the Ottawa river at Graham bay; in the Rideau at Billing's Bridge, Hogs Back and one mile above Black Rapids; in a tributary of the South Nation river one mile southeast of Mountain, Dundas county and in the Blanche river at Jean d'Arc, P.Q.

Small (1883) found it abundant in the Rideau Canal, and said it was occasionally met with in the Rideau and Ottawa rivers and their tributaries.

Johnny Darter. Boleosoma nigrum (Rafinesque).

We have specimens of the Johnny darter from the Ottawa river at Graham bay and Hiawatha Park; the Rideau river at Billing's Bridge and 
Hogs Back; Green creck five miles east of Ottawa and the midkle branch of Castor river, one mile south of Metcalfe.

\section{Rainbow Darter. Catonotus flabellaris (Rafinesque).}

Our only specimen is from the Blanche river at Jean d'Arc, P.Q. Evermann and Goldsborough (1907) record it from "small streams in Quebec, Baird coll., 1853."

\section{lowa Darter. Poecilichthys exilis (Girard).}

This species, unlike the other darters, is found over muddy bottoms in rather stagnant waters. Our specimens are from Constance lake; from a muddy, almost dry creek at Hardwood Plains; and Ramsay lake near Masham Mills, P.Q.

\section{Small-mouth Black Bass. Micropterus dolomicu Lacépède.}

Small-mouth black bass occur in many of the waters of the Ottawa region. To some of these they were not native and it is important to trace, if possible, the original distribution of the species in the region.

In 1883 Small said they occurred in "most of the waters around here. . . Some very fine black bass are to be found in the deep water of the dam above Hogsback on the Rideau, and in the bays of the Ottawa. . . . In the lakes of the Rideau River, and in the lakes of Ottawa County very large ones are caught, Lake Bernard being perhaps one of the most prolific places. A very large specimen ... caught in Lake Bernard and weighing $5 \mathrm{lbs}$. $83 / 4 \mathrm{oz}$., being one of, if not the largest on records here."

In the first annual report of the Ontario Fisheries Branch for the year 1899 it is stated that bass weighing more than four pounds were to be had within three miles of the city of Ottawa.

According to $\mathrm{Mr}$. McCuaig the bass originally occurred in the Ottawa and Rideau rivers and in the Gatineau as far north as lake Baskatong, lake Piscatosin (connected with Baskatong), Petawaga lake, also in Rock lake on Tomassine river. They also occurred in the lower Blanche river. In 1908 they were introduced into lakes Lapêche (Wilson's), Philippe, Harrington (Mousseau), Meach, Thorne (Philip). Other lakes in which they have been introduced include: Bernard (about 1900), Johnston (about 1902), Blue Sea (about 1898), Pemichangan (about 1897 or 98 . From here they worked down to Thirty-one-mile lake), Gardiner, McMullin, Wakefield, McArthur, (Dowler) Grand, Dam, Lower Dam, McGregor (in 1907) and Girard; Ellsworth and Houston on a tributary of the Lievre; Partridge, Letourneau and Wallingford drained by Rainville creek, 
a tributary of the lower Blanche; in Marble, Clair and Ecluse lakes and in Gauvreau lake. Bass were also introduced into the following lakes of Upper Blanche in 1912 and 1920: Lady, Smallion, Hawk, Gull and La Blanche, Long and the Blanche river below these, and into Simon Lake in 1925. According to Small (1883) "many of the bass in that bay (Campbell's bay, Ottawa river) were brought from the Bay of Quinte or from the Ottawa lakes.

Bass were first introduced into Meach Lake about 1908 when 28 fingerlings, 3 to $3 \mathrm{r} / 2$ inches long. were released in the lake. Five years later, 7 specimens taken from the lake, together weighed 28 pounds. At the time of the introduction minnows were abundant but are now scarce. This is similar to the experience in Cache and some other lakes in Algonquin Park in which with the increase in numbers of the bass, small fish on which they feed have become almost non-existent. Scarcity of food thus limits the numbers and rate of growth of bass in such places. Eight specimens of bass ranging in length from 6 to 11 inches taken in Meach lake by Mr. J. A. Rodd during the latter part of the summer of 1937 were examined by Mr. $\mathrm{K}$. H. Doan of the Ontario Fisheries Research Laboratory, University of Toronto. Mr. Doan's report says that “the bass of Meach lake grow more slowly than those of some other bodies of water at approximately the same latitude."

It is unusual in nature to find bass and trout occurring in the same water except in large lakes such as the Great Lakes. Competition usually results in the elimination, sooner or later of either bass or trout from small and medium-sized lakes. There is evidence in many cases of diminution in the numbers of trout following the successful introduction of bass. The introduction of bass into Marston trout waters is especially to be regretted because of the unique character and restricted distribution of this trout.

Large numbers of bass were formerly caught and sold commercially. Probably both species were included but the small-mouth undoubtedly constituted the bulk of the catch.

The following selection from the statistics of the catch, taken from the reports of the Department of Marine and Fisheries, will give some indication of the extent of this fishery. As in the case of other commercial catches, the areas for which reports are given differ from period to period. From an examination of these figures it will be noticed that when the catch for the Ottawa and Gatineau lakes is given separately in the earlier years the whole catch of bass came from the Gatineau lakes but that in later years the catch in the Ottawa exceeded that of the Gatineau area. As in the case of maskinonge it will be noticed that commercial fishing for these fish continued in Quebec for some years after it had ended in Ontario. 


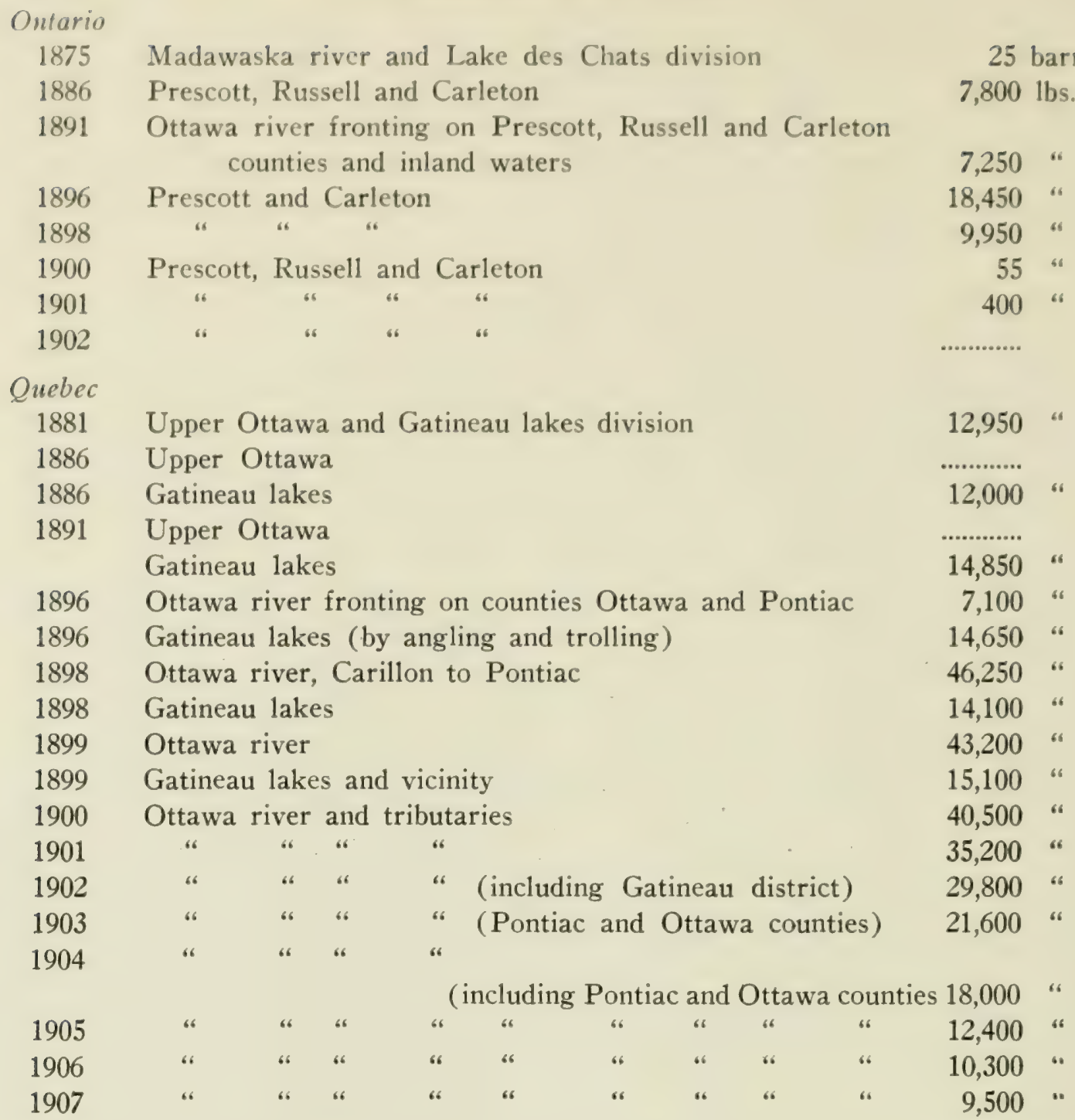

For the years 1908 to 1916 inclusive, the catch in the Ottawa district is not listed separately from that of the other inland districts.

The returns for 1917 to 1924 inclusive indicate that no bass were taken commercially in the Ottawa region, but from 1925 to 1936 considerable quantities were taken in Pontiac county, as indicated by the following records.

\begin{tabular}{|c|c|c|c|}
\hline 1925 & 100 lbs. & 1931 & $900 \mathrm{lbs}$ \\
\hline 1926 & 200 “ & 1932 & 1,200 “ \\
\hline 1927 & $200 \cdots$ & 1933 & 1,500 “ \\
\hline 1928 & 200 “ & 1934 & 1,500 “ \\
\hline 1929 & 200 “ & 1935 & 1,500 “ \\
\hline 1930 & 600 “ & 1936 & 1,400 “ \\
\hline
\end{tabular}

In 1929 and 1930, one hundred and two hundred pounds respectively are reported for Labelle county. No bass are reported for any of the counties in the Ottawa region for 1937. 
Large-mouth Black Bass. Aplites salmoides (Lacépède).

The large-mouth black bass is not as widely distributed as the smallmouth species. It is found in the Ottawa and Rideau rivers and in a number of tributary streams on the Ontario side. Small (1883) said it, "abounds in the Rideau Canal, and is found in all the rivers here, but more sparingly (i.e. than $M$. dolomieu). Large ones are taken in Leamy's Lake weighing up to 2 lbs."

We have specimens from Rideau river at Billing's Bridge and Hogs Back, Black Rapids creek, Green's creek five miles east of Ottawa, King's creek and Steven's creek two miles northwest of Kars.

\section{Blue-gill Sunfish. Helioperca macrochira (Rafinesque).}

We have specimens of this sunfish from Rideau lake and from the Rideau Canal at Merrickville. Small (1883) records it under the name Lepomis auritus as follows, "often found associated with it (i.e. Eupomotis gibbosus) and almost as numerous." Either Small was in error or the species has since decreased in numbers.

\section{Pumpkinseed Sunfish. Eupomotis gibbosus (Linnaeus).}

The pumpkinseed is an abundant and widely distributed species. We took specimens in the Ottawa river at Graham bay and Hiawatha Park; the Rideau river near the mouth of Black Rapids creek and one mile above Black Rapids; Walt's creek near Connaught Rifle Ranges, Ottawa; Bear creek near Carlsbad Springs; McEwen's creek near Ramsayville; in Steven creek near North Gower and Kars; middle and south Castor river; Jock river, three miles northeast of Richmond and one mile east of Dwyer Hill; tributary of Jock river north of Fallowfield; Nichol's creek; Brassill's creek; King's creek; Constance lake. On the Quebec side the pumpkinseed was taken in the Blanche river at Jean d'Arc and in McGregor lake. It is said not to have been native to Meach lake, but to occur. there now. Small (1883) says, "Common everywhere except in the sharp running mountain streams of the Laurentian range, and yet I remember once being horribly disappointed when trout fishing below Old Chelsea, at finding after a smart tug at my line ... a miserable little sunfish instead of the expected trout." "Minnow lake, Hull", Anonymous 1865.

\section{Rock Bass. Ambloplites rupestris (Rafinesque).}

The rock bass probably occurs naturally wherever the small-mouth black bass does. Our specimens are from Rideau river at Billing's Bridge, Hogs Back and one mile above Black Rapids; Walt's creek near Connaught Rifle Ranges, Ottawa; Green creek five miles east of Ottawa; Jock river 
three miles northeast of Richmond; middle branch Castor river, one mile south of Metcalfe; Blanche river, Jean d'Arc, P.Q.; and McGregor lake, I'. ().

It is possible that rock bass were accidentally introduced into McGregor lake along with the black bass or, as Mr. McCuaig suggests, by fishermen "who took same for bait and dumped what was not used."

\section{Calico Bass. Pomoxis sparoides (Lacépède).}

The calico bass must be near its northern limit at Ottawa. Our only specimens are from the Rideau river at Hogs Back and one mile above Black Rapids, and from Steven creek, one mile northwest of North Gower.

Halkett (1907A) recorded this species from "Rideau canal near Ottawa; Lewis' dam vicinity of Ottawa; Gilmour's Mills, P.Q., near Ottawa and Rideau river, Ontario." Montpetit (1897) recorded it from "the Ottawa."

\section{Brook Silverside. Labidesthes sicculus (Cope).}

The only record I have of this species in the Ottawa district is afforded by specimens taken by Mr. Claude Jnhnson from pools along the Rideau river.

\section{Sheepshead. Aplodinotus grunniens Rafinesque.}

The sheepshead is occasionally taken in the Ottawa, both above and below the Chaudière falls. Small (1883) reported it as "found in the Ottawa, but is by no means common, though formerly it is said to have been quite abundant. . . . Last summer some very fine specimens . . . taken from the river near Templeton."

Small and Lett reported in 1884 that the sheepshead which "years ago was abundant, but which of late has been a rarity in the Ottawa River, is again making its appearance in our markets" and in 1885 "the number of sheepshead offered for sale on our market is increasing."

\section{Miller's Thumb. Cottus cognatus Richardson.}

The miller's thumb is found over rocky or stony bottoms and so should be found in some of the streams of the Gatineau district. Our only specimens came from the stream at Graham Bay station and from a spring creek near Ellwood station, south of Ottawa. Under the name Uranidea cognata Small (1883) said, "The only places I have met with this fish are in a small stream north of Buckingham, and in the Chelsea trout stream. 
Brook Stickleback. Eucalia inconstans (Kirtland).

This stickleback is found in small streams, especially over a muddy bottom, sometimes in muddy bays of lakes. It was taken in streams at Graham Bay station and Hardwood Plains; in Black Rapids creek; Brassill's creek and in tributaries of the Jock river, north of Fallowfield and two miles southwest of Richmond, also in Constance lake.

Halkett (1906 A \& B) had it from Stittsville and Small (1883) reported it as "common in ditches, brooks and ponds, and especially in Lake Flora in Hull.”

Small's record of the four-spined stickleback (Apeltes quadracus) was no doubt an error as this species is entirely marine.

The anonymous writer of 1865 also recorded both the four-spined and five-spined sticklebacks. The brook stickleback which usually has five spines on its back sometimes has the number reduced (Dymond 1927). This is probably the condition which led to the report of Apeltes quadracus.

Nine-spined Stickleback. Pungitius pungitius (Linnaeus).

The nine-spined stickleback is a fish of the open waters of lakes. Halkett (1906A) reported it from Lac des Isles, Gatineau district.

Two-spined Stickleback. Gasterosteus aculeatus Linnaeus.

This species, which is essentially marine in distribution, penetrates the St. Lawrence drainage as far as the head of Lake Ontario. The only specimens we have from the Ottawa region were taken in Masham creek near Masham Mills, P.Q. Specimens were taken there on May 25, 1935, by F. P. Ide and S. McKinlay and on June 27, 1937, by Gordon Bucher.

\section{Burbot; Ling. Lota maculosa (Le Sueur).}

This fresh water member of the cod family is found most commonly in deeper lakes. Our only specimen, a young one, was taken in the Petite Rivière Blanche, Quebec.

Small (1883) said it was "found in the bays of the Ottawa", and Halkett (1906B) had it from lake Deschenes and Rideau river near Ottawa. 


\section{LITERATURE}

Anonymous, 1865. Notes on the lakes and lake fishes in the vicinity of Ottawa, C.IV. No. 1-Minnow lake by a member of the Isaac Walton Club (Dr. Edward Van Cortlandt?) Ottawa Citizen, June 21, 1865.

Chambers, E. T. D., 1896. The ouananiche and its Canadian environment. New York. Coleman, A. P., 1922. Glacial and postglacial lakes in Ontario. Univ. Toronto Stud., Biol. Ser., 21, Pub. Ont. Fish. Res. Lab. 10.

Dymond, J. R., 1927. The fishes of Lake Nipigon. Univ. Toronto Stud., Biol. Ser. 27, Pub. Ont. Fish. Res. Lab. 27.

Dymond, J. R., 1937. New records of Ontario fishes. Copeia, 1937, No. 1, p. 59.

Evermann, B. W. and E. L. Goldsborough, 1907. A check list of the freshwater fishes of Canada. Proc. Biol. Soc. Wash. 20: 89-120.

Forbes, S. A. and R. E. Richardson, 1908. The fishes of Illinois. Nat. Hist. Surv. III., vol. III.

Garman, Samuel, 1893. The Lac de Marbre trout. A new species. Science 22: 23.

Halkett, Andrew, 1906A. Report of the Canadian Fisheries Museum. 38th Ann. Rpt. Dept. Mar. \& Fish., Fisheries Branch. App. No. 14, pp. 362-370.

Halkett, Andrew, 1906B. A list of fishes of the Ottawa district, in Zoological Report 1905-6. Ottawa Nat. 20:60.

Halkett, Andrew, 1906C. Correspondence. Ottawa Nat. 20: 50.

Halkett, Andrew, 1907. Report of the Canadian Fisheries Museum. 40th Ann. Rpt. Dept. Mar. \& Fish. Fisheries Branch. App. No. 14, pp. 321-349.

Halkett, Andrew, 1912. Natural History Report. 45th Ann. Rpt. Mar. \& Fish. Fisheries Branch. P. 348.

Halkett, Andrew, 1914A. Check list of the fishes of the Dominion of Canada and Newfoundland. Ottawa.

Halkett, Andrew, 1914B. Natural History Report. 47th Ann. Rpt. Dept. Mar. \& Fish. Fisheries Branch. Pp. 343-367.

Hubbs, C. L. and M. B. Trautman, 1937. A revision of the lamprey genus Ichthyomyzon. Mus. Zool., Univ. Mich., Misc. Pub. 35.

Huntsman, A. G., 1917. The lampreys of eastern Canada. Ottawa Nat. 31: 23-27.

Jordan, D. S. and B. W. Evermann, 1896. The fishes of North and Middle America. U.S. Nat. Mus., Bull. 47.

Lemieux, E. E., 1906. Small suckers in Lake Pembina, Lievre district. Ottawa Nat. 20: 59 .

Macdonald, Ewen, 1938. Shad still run the Ottawa. Rod \& Gun, February, 1938.

Macoun, John et al., 1903. Report of the Zoological Branch, 1902. Ottawa Nat. $17: 34-36$.

Montpetit, A. N., 1897. Les poissons d'eau douce du Canada. Montreal.

Nash, C. W., 1908. Check list of the fishes of Ontario. Dept. Education, Toronto.

Small, H. B., 1865. The animals of North America. Series II. Freshwater fish. Montreal. 
Small, H. B., 1866. The Canadian handbook and tourists' guide. Montreal.

Small, H. B., 1883. Fishes of the Ottawa district. Ottawa Field-Nat. Club. Trans. 4 : 31-49.

Small, H. B., 1893. My aquarium. Ottawa Naturalist $7:$ 33-48.

Small, H. B. and W. P. Lett, 1884 \& 1885. Report of the Zoological Branch. Trans. Ottawa Field-Nat. Club. 2: $150 \& 283$.

Van Cortlandt, Edward, 1865. Fishes of the Ottawa. A digest of an essay on the fishes of the Ottawa river, with its tributaries and some of the contiguous lakes-read before the Natural History Society on Friday, 24th Nov., 1865. Ottawa Citizen, Nov. 29, 1865.

Wright, Ramsay, 1892. Preliminary report on the fish and fisheries of Ontario. Report Ontario Game \& Fish Commission. 



\section{CONTRIBUTION S \\ OF THE}

ROYAL ONTARIO MUSEUM OF ZOOLOGY

This series contains reports of Museum studies, including faunal surveys. Except where otherwise stated the price is twenty-five cents a copy.

1. Faunal Survey of the Lake Nipigon Region, Ontario, by J. R. Dymond, L. L. Snyder and E. B. S. Logier. 58 pages.

2. A Faunal Survey of the Lake Abitibi Region, Ontario, by the staff of the Royal Ontario Museum of Zoology. 46 pages.

3. A Faunal Investigation of King Township, York County, Ontario, by L. L. Snyder and E. B. S. Logier. 42 pages (out of print).

4. A Faunal Investigation of Long Point and Vicinity, Norfolk County, Ontario, by L. L. Snyder and E. B. S. Logier. 120 pages (out of print).

5. Some Account of the Amphibians and Reptiles of British Columbia, by E. B. S. Logier. 26 pages (out of print).

6. A Study of the Sharp-tailed Grouse, by L. L. Snyder. 66 pages.

7. The Passenger Pigeon in Ontario, by Margaret H. Mitchell. Records of the history of the now extinct wild pigeon (Ectopistes migratorius) in Ontario. Paper, \$1.00. Cloth, \$1.50. 181 pages.

8. The Distribution of Breeding Birds in Ontario, by James L. Baillie, Jr., and Paul Harrington. 134 pages.

9. Some Freshwater Fishes of British Columbia, by J. R. Dymond. 14 pages.

10. The Birds of the Lake St. Martin Region, Manitoba, by T. M. Shortt and Sam Waller. 51 pages.

11. Baird's Sparrow, by B. W. Cartwright, T. M. Shortt and R. D. Harris. 44 pages.

12. Ontario and its Avifauna, by L. L. Snyder, and The Museum's Bird Collection, by J. L. Baillie. 14 pages.

13. Birds of Algonquin Provincial Park, Ontario, by D. A. MacLulich. 47 pages.

14. A Faunal Investigation of Western Rainy River District, Ontario, by L. L. Snyder, 57 pages.

15. The Fishes of the Ottawa Region, by J. R. Dymond, 43 pages. 

